Florian Urban, Glasgow School of Art, f.urban@gsa.ac.uk

\title{
Postmodern Architecture Under Socialism - The Ascension Church in Warsaw-Ursynów
}

\author{
The Ascension Church, built in the tower block district of Warsaw-Ursynów 1980-85 to a design by Marek \\ Budzyński and Piotr Wicha, reveals the mechanisms of architectural change under the declining socialist regime \\ in Poland. Based on archival documents, interviews, and press reviews, this article traces the process of form \\ finding and construction of what became one of Poland's best-known postmodern buildings. \\ The author argues that in the context of the building postmodern design occupied and widened the cracks that \\ had appeared in the authoritarian socialist regime since the 1970s. This is evident in the 'speaking' architectural \\ forms that communicated nonconformist ideas, at the level of decision-making and resourcing 'outside the \\ plan,' and in relation to post-functionalist city planning around the building. \\ The author also argues that the impact of the Ascension Church, and by extension of similar postmodern \\ buildings in Poland, was based on a reception of postmodernism different to that in Western Europe and North \\ America. Rather than being related to capitalist exuberance and ironic criticism of the architectural discipline, \\ postmodern architecture became connected to a search for lasting values that transcended the mundane socialist \\ every-day life. At the same time it also served as a vehicle for national/patriotic narratives that are influential in \\ Poland to date.
}

Keywords: postmodern architecture in Poland; socialist architecture; WarsawUrsynów; Marek Budzyński; postmodern urban design; sacred architecture

\section{A Postmodern Showcase Building}

Walking through the centre of Ursynów, a typical modernist tower block district on Warsaw's southern periphery, one is taken by surprise. On a small square, off a six-lane thoroughfare flanked by serial ten-storey high-rises, stands the opulent Ascension Church (Kościót Wniebowstapienia Pańskiego) (figure 1) It boasts a curved, quasibaroque façade with a huge, lavishly ornamented cross that at the same time serves as the main entrance. The cross is flanked by two stubby Romanesque columns. The church is part of a greater ensemble that includes a church hall, a presbytery and other adjacent buildings with similar, historically inspired details: a bell-tower reminding of a medieval city gate (figure 2), a side entrance with a flamboyant flight of steps (figure 3), columns with natural stone plinths, and a facsimile of a historic well. The ensemble was not, as one might assume, an addition of the post-socialist period, but rather begun in 1980 , ten years after the district was founded, and nine years before the collapse of the socialist regime. The contrast to the bleak prefabricated blocks in the wider area is even more astonishing when one learns that both share the same designers, a team around the architects Marek Budzyński and Piotr Wicha. And yet, as will be argued below, the seemingly paradoxical ensemble is much more characteristic of late socialist Poland than one might expect. [figure 1 near to here] [figure 2 near to here]

Based on archival documents, publications and interviews, this article traces the genesis of the building and its design, which, based on traditional typologies, historical quotations and conspicuous ornamentation, will be referred to below as postmodern. It argues that the Ascension Church is an example of how such architecture occupied and possibly widened the cracks that had appeared in Poland's ailing socialist regime since the 1970s. Postmodern architecture stood for nostalgic ideas about a national culture centred around the Catholic Church, and at the same time for a forward-looking urbanism promoting social cohesion. This significance was decidedly different from those in Western Europe and North America at the same time, where postmodernism was most often connected to an advanced stage of the capitalist economy and criticism 
of the modernist mainstream of architectural theory and aesthetics. ${ }^{1}$ Hence this article argues that, rather than carrying a fixed and well-defined meaning across the globe, postmodern architecture was heterogeneous, flexible and adaptable to particular sociopolitical contexts.

In the ensuing discussion it will be shown that the Ascension Church both contributed to and reflected the outcome of the socio-political transformation in the last decade of the Polish People's Republic. Connected to the incremental change under a seemingly intransigent authoritarian system, the design of the building relied on several themes that would play out in Poland over the following decades: the rise of nationalist ideas that had been present, in one or the other way, since the pre-World War II-period; the increasing influence of the Catholic Church; and the growing significance of postfunctionalist city planning principles, such as small scale, mixed use, and the involvement of multiple actors and influences.

Postmodern architecture in Poland, in recent years, has become subject to intense research. ${ }^{2}$ There is also increasing scholarship on the major wave of church construction between 1975 and 1989 — some sources speak of over 1,500 churches being built in this period, which were often but not always in a postmodern style. ${ }^{3}$ The Ascension Church prominently figures in the interviews that the architect Marek Budzyński has given over the last forty years. ${ }^{4}$ It is also mentioned in local historical studies on the Ursynów tower block development. ${ }^{5}$ Against this background, this article will present the design of the Ascension Church in the context of a changing political and economic context, which was not only different from that of Western Europe, but also, for example, from neighbouring socialist East Germany.

\section{Architectural Innovation Under a Weakening Authoritarian Regime}

Postmodern architecture developed under particular circumstances. First, in contrast to what one might expect in a socialist country, nationalist ideas remained strong in Poland throughout the postwar period. Apparently oppositional groups, such as the Catholic Church and the socialist rulers, in particular the 'national communists' under Party leader Władysław Gomułka (in office 1956-70), engaged in patriotic rhetoric with similar zeal and appropriated similar concepts such as the historic continuity of the Polish nation and the need for continuous resistance against its enemies. ${ }^{6}$ Postmodern eclecticism thus developed in a context in which 'national tradition,' however construed, was neither considered outdated nor inappropriate, but rather an essential part of modern culture.

Second, late socialist Poland was an authoritarian regime in a state of disintegration. The country was riddled by economic decline and repeated waves of popular protest against the all-encompassing rule of the Polska Zjednoczona Partia Robotnicza (PZPR, Polish Unified Workers' Party). ${ }^{7}$ The construction of the Ascension Church, like other postmodern buildings, happened under conditions of economic hardship and political upheaval. Under Party leader Edward Gierek (in office 1970-1980), Poland first experienced a moderate rise in living standards financed by foreign credits, and subsequently increasing economic difficulties, to the extent that by the early 1980s there were shortages in the most basic products. ${ }^{8}$ At the same time the 1970 s was also a period of relative political freedom and growing protest connected with the Workers' Defence Committee (founded in 1976) and the Solidarity Trade Union (founded in 
1980). In the wake of the 1978 election of John Paul II, the first Polish pope in history, visible religious practice and the presence of the Church in public life increased. While the hopes for lasting political reforms were crushed for the time being by the appointment of General Wojciech Jaruzelski as Party Leader in 1981 and the subsequent declaration of martial law, the seed of architectural non-conformism continued to grow during the times of repression and well beyond the time of the eventual collapse of the socialist regime in 1989.

Against this background the extraordinary design of Ascension Church resulted from three factors that were not causally related but jointly generated a particular momentum for postmodern architecture. Firstly, from the late 1970s onwards, postmodernism was increasingly discussed as a means of breaking the monotony of functionalist tower blocks, re-introducing meaning and individual expression in architecture, and reconnecting to a national tradition that had allegedly been lost. Secondly, restrictions on church construction were eased in the mid 1970s and, thirdly, economic reforms that were to end the crisis were introduced in the 1980s and set Poland on a course towards a market economy, which gave increasing leeway for architects and builders to operate 'outside the plan' and to realize individualized design. ${ }^{9}$

The first factor, new design influences, was connected to less restrictive censorship practices and increasingly permeable international borders. Postmodernism at the time was widely discussed in Polish architectural circles, and there is no evidence that the authorities attempted to restrict or influence the debate. ${ }^{10}$ Twice, the approach made headlines in the country's prime architectural journal, Architektura. The May 1979 edition, entitled 'Co dalej?/What next?' showed Charles Moore's Piazza d'Italia in New Orleans on the cover and discussed textbook projects of international postmodernism, including Enrique Ciriani's Residences in Saint-Denis near Paris, Rob Krier's Ritterstraße development in West Berlin and Thomas Gordon Smith's Long House in Carson City, Nevada. ${ }^{11}$ The editors also introduced the ideas of theorists such as Peter Eisenman, Robert Venturi, Philip Johnson and Charles Moore, not by translating original texts, but rather by summarizing their work and reprinting articles from West Germany and the United States. ${ }^{12}$ These publications tended to stress postmodernism's search for historical continuity in architectural style and the use of historic quotations.

Among the few Polish examples mentioned in the number was a prize-winning, unrealized 1975 project for the rebuilding of the ruined nineteenth-century fortress Warsaw Citadel into a historically inspired museum landscape. The architect was Marek Budzyński, who five years later would design the Ascension Church. Together with his co-author, Andrzej Kiciński, he expressed a commitment with 'continuity, both in a historical and a landscape sense. ${ }^{, 13}$ The other Polish project, a regionalist summer house near Poznań by Jerzy Buszkiewicz, was connected to a national style and the 'yearning to define ourselves by architectural form,' which, according to the architect, in Poland 'has never disappeared, so we cannot talk about a re-birth.' 14 This national undertone and the collective effort to 'search for a national style' turned out to be significant for the subsequent course of postmodern architecture in Poland, which will be discussed in the next section. ${ }^{15}$

The second factor-relaxing the restrictions on church construction-was a political move by Party leader, Edward Gierek, and connected to his attempt to appease the political opposition. Although never officially proclaimed, the new policy started 
around 1975, when it became progressively easier to receive permission for church construction. ${ }^{16}$ This was welcomed by the majority of the population who, despite several decades of officially promoted atheism, continuously attended church. In 1987 the socialist authorities estimated that 70 per cent of Warsaw residents were practicing Catholics, and that religiosity had risen significantly after the appointment of John Paul II. ${ }^{17}$ From the perspective of the embattled rulers, enabling church construction was also a gesture aimed at those elements of the opposition who opposed the strikes and called for moderation, which included most of the Church hierarchy. ${ }^{18}$ The fact that the resulting churches were often designed in postmodern styles was based on the particular context of their construction. They were less regulated than buildings sponsored by the central planning authorities and thus lent themselves to experimentation. They were also built with more resources, both formal and informal. This will be discussed further below.

The third factor, the crisis that eventually led to economic reforms and the establishment of a private sector, went along with a decreasing interest in architectural design on the part of the socialist Party rulers. ${ }^{19}$ By the 1980 s there was no longer an official architectural policy comparable to that of the 1950s and 1960s that had first promoted Stalinist neoclassicism and later functionalist modernism. The housing shortage was as pressing as ever, and cities were in dire need for public works. But due to a slacking economy government measures were patchy and no longer based on a comprehensive vision. In light of increasing political protest and deteriorating food supply, the Party rulers simply had other matters to attend to. ${ }^{20}$ They half-heartedly continued to support functionalist modernism, but at the same time were not opposed to innovations whenever they promised to improve the housing situation. By and large, architectural design disappeared from the discussions in the Politburo and other Party committees.

More than policy documents, it was committed individuals who secured spaces for architectural innovation. In the case of the Ascension Church these were a recently appointed (in 1975) parish priest in his thirties, Tadeusz Wojdat, who had a great talent for management (figure 5), and a strong-minded architect of the same age, Marek Budzyński, who had been the lead architect of the Ursynów estate since 1971. Their enthusiasm and their unusual collaboration under adverse conditions underpinned the Ascension Church's unorthodox design. [figure 5 near to here]

Such individually-driven postmodernism, based on decreasing political control and increasing economic freedom, was distinctive for Poland in the wider context of the Soviet sphere of influence at that time. It was different, for example, from the neighbouring German Democratic Republic, where neo-traditional architecture was was revived to support the interests of the socialist rulers. ${ }^{21}$ While East German postmodern architecture was about image marketing for the regime, its Polish equivalent catalysed alternative visions. This will be discussed in the following section.

\section{Semiotics and Patriotism}

The three factors-namely, new stylistic influences, relaxing restrictions on church construction, and economic reforms - had an impact at all levels of the decisionmaking, which generated the final design. The impact of international postmodernism was noticeable despite the conspicuous absence of the term in the early phase of the 
project. None of the early reviewers mentions the word 'postmodern,' and neither was it present in the minutes of the Church commissions or in statements by the architects. At the same time the most discussed stylistic innovations of the building appear to be taken from the selective reception of the postmodernism that were discussed in the previous section: the semiotic qualities and the abilities of the building to 'speak,' as well the ostentatious eclecticism and the references to particular historic styles.

Whenever non-modernist qualities became the subject of broader discussion it was under the umbrella of 'national tradition' or polskość (Polishness). In January 1981, when construction had barely started, a journalist praised the 'intentional reference to the tradition of Polish sacred architecture.' ${ }^{22}$ Similar interpretations could soon be read all over. The journal Architektura in 1982 observed that the altar wall as reminiscent of counterreformation-age churches in the Małopolska region, and the exterior stairs (figure 3) referred to the late-sixteenth-century Baranów Palace, a schoolbook image of national glory and a remnant of a purported 'Golden Age. ${ }^{23}$ Critic Henryk Drzewiecki in 1983 praised the rootedness in Polish tradition, and that the fieldstones in the entrance gave the façade a 'native beauty' (rodzime piękno). ${ }^{24}$ Art critic Paweł Giergoń called Budzyński 'the most Polish of all architects. ${ }^{25}$ And also priest Wojdat saw 'Polishness' as one of the foremost design qualities. He praised the references to 'old Polish architecture' and to 'values particular to Polish history. ${ }^{26}$ In addition, the architects pointed to intentional references to a national tradition. Budzyński's collaborator, Piotr Wicha, saw historic references as particularly significant in a country where 'tradition has been destroyed so many times,' and Budzyński even described his design as 'related to the Polish constitution of 1791,' possibly as an oblique reference to the historic achievements of the Polish nation. ${ }^{27}$

This interpretation of historical quotations was very different from, for example, the situation in East Germany, where neo-historical forms catered to a non-specific nostalgic longing, but at the same time sought to avoid references to a national past haunted by memories of Nazi crimes or working-class misery. ${ }^{28}$ In Poland, by contrast, the nation and national references retained unambiguously positive connotations throughout the late twentieth century, and were similarly mobilized by the socialist regime and by the national-Catholic opposition. ${ }^{29}$ Since few state-sponsored buildings were erected during the crisis of the late 1970s and 1980s, and since the most prominent buildings were financed by the Church and the fledgling private market, these clients often inscribed national romantic/patriotic content into them. Their historic references were often just as generic as those in East Germany, but the associated narrative was clear. Against economic insecurity and ideological uncertainty there was a vision of national unity under the guidance of the Catholic Church. Along those lines also at Church forums, symbolic forms and references to historic precedents were mostly discussed in reference to 'Polishness.' following section.

At a formal level there is little that identifies Budzyński's façade as particularly 'Polish.' There are generic elements that an observer trained in architectural history might trace back to Brunelleschi's fifteenth-century Santo Spirito Church in Florence, Vignola's sixteenth-century Il Gesù in Rome, or baroque village churches in many European countries. There is also evidence that Budzyński received influences from Mexico, where during his 1978 visit for the conference of International Union of Architects he was impressed by colonial baroque churches dominating a town square 
with their shiny white façades. ${ }^{31}$ Accordingly, early models show the Ascension Church with a white stucco façade, which remained unrealized purely for material shortages in martial-law Poland (figure 5). ${ }^{32}$ Eventually, however, the symbolic power of Budzyński's eclectic postmodernism operated through collapsing 'non-modern' with 'non-socialist' and 'Polish.' The building became a screen for the prevalent narratives at the time: national revival as a remedy for a modern life perceived as unsatisfactory, and spirituality as a carrier of values deemed superior to 'scientific Marxism.' [figure 5 near to here]

The latter is for example reflected in the representation of the Ascension Church by one of Poland's best-known filmmakers, Krzysztof Kieślowski. In his 1988 movie Dekalog $I$, which was shot in the Ursynów district, he presents the computer as a false god and opponent of true faith. ${ }^{33}$ The antagonism is symbolised by the contrast between Ursynów's functionalist tower blocks and the postmodernist Ascension Church that repeatedly appears in the background. The church is also the setting of the final scene, in which the protagonist, devastated by the death of his twelve-year-old son, turns to faith to come to terms with his shattering experience. The 'entrance through the cross' contains the promise of a deeper truth beyond the fallacies of a scientific world-view, which lay at the bottom of the monotonous tower blocks, much like the protagonist's 'heretic' belief in the power of the computer. Kieślowski's imagery evidences the symbolic dimension of postmodern architecture in the Polish context, which is connected to a spiritual truth, and pitched against the emptiness and superficiality not only of socialist everyday life, but rather of a secular existence as such.

In contrast, a discussion of architectural principles, which was characteristic for the discourse on postmodernism in the West at the time, was conspicuously absent in the Polish debate. A good example is the interpretation of the 'hanging columns' in the Ursynów church, which absolutely do not do what columns are supposed to do: they do not support the roof (figure 6). Rather, they are an ornamental element that both divides and unites the main body of the church from the side nave - a move that the architect explained as purely aesthetic and a critic celebrated as a 'heroic gesture. ${ }^{34}$ The numerous popular interpretations nonetheless show the difference in the perception of postmodern architecture in Poland: that the 'hanging columns' were supposed to prevent State Security officers from hiding and secretly recording the mass; that they were removed symbolically to unite the Polish people under the umbrella of the Church; or that they should make it clear that the church, above all, does not rest on stone pillars but on the parishioners' faith. ${ }^{35}$ [figure 6 near to here]

The canonical Western interpretation, along the lines of Robert Venturi or Peter Eisenman, was conspicuously absent: that the 'hanging columns' could be a semiotic device to question the functioning or architectural logic, or that that they could be an ironic statement on the no-longer-venerated classical orders. The interpretative detail shows the extent to which the postmodernism of the Ascension Church operated at a different level: it was interpreted along the lines of national and religious narratives rather than architectural principles, and its 'speaking' elements was received in a straightforward and literal way. 


\section{Building a Church in a Socialist Housing Estate}

For the socialist authorities the foremost bone of contention was not postmodernism, but rather the construction of a sacred building. Sacred architecture in a socialist housing development was contested, but not as unexpected as it would have been in the Soviet Union, Romania, or East Germany, as religious practice was widespread even among Party officials. For the parish priest Tadeusz Wojdat the four-year-long fight for a construction permit - short by the standards of the time-was first of all a practical necessity in light of a growing congregation, but also reflected the Catholic opposition's struggle for the symbolic occupation of public space in the modernist districts ${ }^{36}$ Postmodern design contributed to this struggle insofar as it gave the building additional visibility due to the sharp contrast with the surrounding tower blocks.

In February 1976 Wojdat first approached the First Secretary of the Warsaw Party Committee, Józef Kępa. ${ }^{37}$ His construction request appeared on the Warsaw Curia's list of construction projects as early as September $1978 .{ }^{38}$ A month later, Warsaw's mayor, Jerzy Majewski, was formally notified. ${ }^{39}$ Governmental consent for the construction of a church was given in March 1980. ${ }^{40}$ Shortly afterwards Wojdat chose Budzyński as designer, first and foremost because the project would have been hard to realize with anyone but the lead architect for Ursynów, who was well connected and headed a large team. ${ }^{41}$ In late July 1980 the Chief Architect of Warsaw, Tadeusz Szumielewicz confirmed the exact location and in October Wojdat's parish was granted property rights. ${ }^{42}$ In September 1980 the project was presented to the Curia. ${ }^{43}$ Planning permission was eventually given in December $1980 .{ }^{44}$ A few weeks later, in January 1981, construction started. (figure 7) [figure 7 near to here]

The conspicuous location, one of the foremost symbolic aspects of the building, resulted from Budzyński's negotiating skills at a crucial moment. The architect remembers this as being facilitated by a helpful coincidence. ${ }^{45}$ In the spring of 1980 , the authorities had already approved the construction of a church, but had not yet agreed on a location. Budzyński learned that a commercial centre, which originally been planned for the had site, was cancelled. At a meeting with members of the Warsaw Party Committee, he therefore asked to be given this site and in return was asked whether he was the brother of a high-ranking Party official called Budzyński. He wasn't, but remained silent, which his interlocutors interpreted as a yes. In retrospect Budzyński was convinced that this helped to gain the approval for the location, which was given in July 1980.

Whether or not this speculation is accurate, the socialist rulers would have had good reasons to give in to a popular request at this particular moment. A few weeks earlier the first strikes had broken out in the Lublin area and rapidly spread across the country. The workers demanded lower food prices and political freedom, and put the regime under increasing pressure. In August 1980 the government signed the Gdańsk Agreement and was forced to recognise Solidarity as the first independent trade union in the Eastern bloc. In September 1980 Edward Gierek was removed from power, and for more than a year, until the declaration of martial law in December 1981, the power of the political opposition was continuously on the rise. Under these conditions, facilitating a building desired by many inhabitants thus aligned with other concessions that the rulers were ready to make in their attempt to calm the protesters.

The subsequent discussions over the design of the Ascension Church coincided this politically unsettled period, and were certainly influenced by the general spirit of hope 
and renewal. Budzyński produced the first model in the summer of $1980 .^{46}$ The design was then accepted first by the Rada Parafialna (Parish Council), a local advisory board of which Wojdat was a member. A Styrofoam model was exhibited at the old church and according to Wojdat did not generate major controversies. ${ }^{47}$ After that came the official consultations with the Church hierarchy. These stretched over more than a year and continued after construction had already started. It was during this phase that the most conspicuous postmodern elements were finalized. These include the flat brick façade, the 'entrance through the cross,' the medieval-style belltower and the large square that became essential for the urban integration of the church building.

A change in Church leadership became an important factor. Cardinal Stefan Wyszyński, Primate of Poland, died in May 1981. His successor, Józef Glemp, according to observers, was more open to architectural innovations than Wyszyński, and eventually approved the design. ${ }^{48}$ The next tiers of approval were the municipal Department of Architecture and Urbanism and, most importantly, Chief Architect Szumielewicz. These were not independent authorities, but reliant on the decisions of the Warsaw Party Committee. Both the Mayor, Jerzy Majewski, and the First Secretary of the Warsaw Party Committee, Alojzy Karkoszka, were presented with architectural drawings through the Curia. However, neither the architect nor the client recall any exertion of influence on the part of the Party. ${ }^{49}$ By and large, Primate Glemp's and the church institutions' design decisions tended to be respected by state officials once permission to build a church had been granted. ${ }^{50}$

Hence, the most significant discussions at a level beyond that of the architect and his team took place within Church institutions. Somewhat surprisingly, however, these were rather mundane and focused mostly on functional details, such as entrance locations, or the connection of particular buildings with the surroundings, and not, as one might expect, the appropriate representation of Christian faith and the image of the Catholic Church. ${ }^{51}$ A forum for these debates was the Rada Prymasowska do Budowy Kościołów (Primate's Council for Church Construction), a Warsaw-based organization within the Church composed of architects and other lay experts and chaired by Bishop Jerzy Modzelewski. ${ }^{52}$

The responsible committee for discussing the design of particular parish churches was the Komisja Artystyczna $i$ Architektoniczna Archidiecezji Warszawskiej (Warsaw Archdiocese Commission on Art and Architecture), which assembled a selection of Primate's Council members. Those present at the meetings of the Archdiocese Commission were in the majority architects and engineers, as well as Bishop Modzelewski. ${ }^{53}$

There is evidence that also in the context of Church institutions Budzyński's individual influence was crucial for achieving the unusual design. The Archdiocese Commission discussed his proposal at seven meetings, which stretched over two years and were characterised by repeated outbreaks of temper. ${ }^{54}$ Commission member Lech Dunin, for example, pointed out that 'any proposal for change suggested by the commission was received by the architects in an authoritatively negative way, requiring long discussions. ${ }^{55}$ Architecture professor Tadeusz Zielinski called the large homogeneous facade 'unrealizable' and insufficiently connected to the section. And his colleague Bolesław Szmidt called Budzyński's design 'very bad architecture' that 'tries to turn scenographic shots into sacred architecture.' At the same time parish priest Wojdat 
pushed for swift approval, and stressed that further delay would put the whole project in danger. $^{56}$

The controversy in the commission was explicitly not rooted 'in the general conception that stands in contrast to modern design' but rather in the difference and quantity of the forms 'provoking disquiet,' in particular the presbytery. ${ }^{57}$ The commission also asked to replace the cross-shaped entrance/window with a solid cross. ${ }^{58}$ In all these aspects, the architects eventually asserted themselves and made only very small changes.

While discussions over design were still on-going, the church was under construction. Moreover, the first drawings had already been published in January 1981 in the Catholic newspaper Tygodnik Katolicki, showing the façade more or less as it was eventually built, a column-lined presbytery and a tall historicised belltower (both presbytery and belltower were later modified). (figure 8 , figure 9) The reviewer enthusiastically praised the homogeneous façade with the cross-shaped entrance. ${ }^{59}$ [figure 8 and figure 9 near to here]

It seems that it was eventually Budzyński's tenaciousness that led to the approval of his bold façade design, the 'speaking' qualities of which were soon commonly understood according to the much-repeated motto 'through the cross to salvation. ${ }^{60}$ Eventually the commission reluctantly signed the project off on 11 September 1981, about nine months after construction had begun, and appointed Zieliński and Kucza-Kuczyński as consultants to give the architects further guidance. ${ }^{61}$

The building thus came to symbolize the strengthened position of the Catholic Church in Polish public life, which Budzyński was even allowed to publicly state under martial law. In a 1982 interview in the official journal Architektura, which probably would not have made it through the censorship organs in the Soviet Union or East Germany, he pointed out that 'in the nearest future... the church will become the most important building in Ursynów. There is no other function that could compete with the church. ${ }^{62}$

\section{Resourcing 'Outside the Plan'}

How was such an opulent postmodern building financed in times of exacerbated economic shortage, and what does this tell about the interaction between Church and state? Like similar churches at the time, the Ascension Church was not financed by the national and municipal planning authorities, but rather by Church funds, parishioners' donations, volunteer work and to some extent hard-currency donations from the West (often by partner congregations or Polish emigrant communities). It would nonetheless be slightly oversimplified to call sacred architecture under socialism 'outside the official logic of urbanization' and 'not part of the political and societal programme' of the People's Republic of Poland, as has been suggested. ${ }^{63}$ The Ascension Church, like similar church buildings, was not popular design as opposed to official architecture. It evolved under economic conditions set by the socialist regime and obtained its particular significance within the political context. As such, it evidences the Catholic Church's increasing influence on a nominally socialist society.

Although oppressed by the regime, the Catholic Church in Poland was always in a stronger position than the churches in any other socialist country. This was reflected not least in material terms. Hundreds of destroyed pre-war churches were rebuilt with state 
funding and remained Church property. ${ }^{64}$ Furthermore, despite the expropriations in the postwar period, the Church remained an important landowner, and received income through lease of land and buildings as well as through the Fundusz Kościelny (Church Fund). ${ }^{65}$ Most profitable were cemeteries, whose burial and maintenance fees constituted a major source of income for the respective parishes. There were also the expected weekly donations na tace ('on the tray') during mass and the yearly donation na kolęde ('at the Christmas visit') during the priest's annual house call. And there were fees for christenings, weddings and funerals, which parish priests were allowed to set at their discretion, which were not published and not taxed, and which could vary significantly between parishes or even from instance to instance. Given that for a believing Catholic there is 'no salvation outside the Church' the right to set the prices for indispensable religious rituals gave parish priests significant financial leverage, irrespective of the fact that many parishioners would happily donate to what they believed to be a good cause. In any case the asymmetric power relation between priests and parishioners was indicative of the Church's on-going socio-economic influence under socialism, which state authorities were unable or unwilling to question and which had a direct effect on sacred architecture.

Through this arrangement the socialist regime also tacitly accepted that the Church continuously possessed sources of income that were unaffected by the exacerbating inflation hitting Poland in the 1980s, as fees and donations could be in-kind. They frequently included building materials, or food that could be exchanged for building services. The fact that many members of the Party elite were at the same time secretly practicing Catholics also gave the priests opportunities to strike informal deals. Architect Jerzy Gurawski, the co-designer of the famous postmodern Our Lady Queen of Poland Church in Głogów (1985-89), concluded that the 1980s were better times for church construction than the post-communist period. Not only was the Church able to run effective construction sites in times of shortage, but it also got locations that it would never get if it had to compete with a capitalist investor. ${ }^{66}$

Also for Ascension Church the access to both formal and informal resources was a decisive factor that allowed for comparatively sophisticated and individualized design. Parish priest Wojdat remembers construction as tenuous, as funds were only secured from one week to another, and both materials and labour were precarious. At the same time workers accepted this insecurity as most of them identified with the project and deemed a new church building to be a worthy cause. About 40-50 regular workers were legally employed by the parish, which in this respect was allowed to act as a quasiprivate developer. ${ }^{67}$ (figure 10) [figure 10 near to here]

Alongside regular Church funds, which included parishioners' donations, there were informal contributions. A Catholic congregation in St Malo in France donated a truckload of cement. ${ }^{68}$ Another one in Paris donated diverse materials. ${ }^{69}$ Volunteers cut and brought wood from the nearby forests to fence in the construction site. ${ }^{70}$ Wojdat also recalled 'the occasional 100 dollars' from foreign visitors supporting the cause. ${ }^{71}$ Such donations made a huge difference at a time when the unofficial exchange rate for 100 dollars was 60,000 złoty, which was three times an average Pole's monthly salary. ${ }^{72}$

Just as important were construction workers who would donate their Saturdays to the project. At some point over 50 skilled volunteers were working at the construction site. In this respect the Ursynów Church was typical of Warsaw's churches of the late 
socialist period, which in contrast to sacred buildings in rural areas were mostly built by skilled workers. ${ }^{73}$ There were also indirect donations, for example when an engineer offered a specially low price. $^{74}$

The postmodernist design with its customised details and labour-intensive ornaments thus reflected the increasing social and economic significance of the Catholic Church, which became even more conspicuous through the contrast with the surrounding tower blocks. Against this background the formal references to the baroque churches of the counter-reformation era, a time when the Church in similar waysch powerfully emerged from crisis, seem to be intentional.

Next to the strengthened position of the Catholic Church these forms were also indicative of a new socio-economic reality under late socialism, which transcended the Fordist model of mass production that had formed the basis of functionalist housing districts such as Ursynów. Just as the power of the centralised planning apparatus was on the wane, the architecture of the church became a showcase for the new stylistic variety and, at the same time, a testing ground for the diversification of both formal and informal economies.

\section{Channelling Post-functionalist Urban Design}

Possibly the most wide-reaching contribution of the Ascension Church to the built environment was related to post-functionalist urban design, which is habitually referred to as postmodern. ${ }^{75}$ The debates around the building and the spaces that were laid out in its immediate surroundings reflected the criticism of monofunctional spaces and repetitive blocks, which also in socialist Poland, despite censorship, made it to journals and newspapers. ${ }^{76}$ In this respect the church ensemble paralleled the cautious approaches taken in other socialist countries at the time to modify the straitjacket of functionalist estate planning and industrialized construction. The Tócóvölgy Estate in Debrecen (Hungary), the neo-historical panel buildings in the centre of Halle (East Germany), or the reinvented old town Nikolaiviertel in East Berlin evidence such modifications, as they provided housing in small-scale, neo-historical environments.

The Ursynów example adopted particular aspects of anti-functionalist criticism that were less prominent in the East German or Hungarian cases, such as the search for a heterogeneous 'spatial grammar' and diverse actors in the planning and construction process. These were related to pattern language approaches based on the work of Christopher Alexander, who had a particular influence on Budzyński. ${ }^{77}$ Along these lines Budzyński and his team aimed to create what in the Polish context was referred to as przestrzeń kameralna ('chamber spaces'), small-scale interconnected sequences of space designed to generate cosiness and familiarity. ${ }^{78}$ They paralleled the search for 'hospitable' architecture theorized at the same time by Dutch structuralists such as Aldo van Eyck or Herman Hertzberger, whose influences on post-functionalist urban design were noticeable in many countries. ${ }^{79}$

The Ascension Church embodied some of the ideas, which Budzyński and his team had already attempted to apply to the Ursynów scheme as a whole, but which were eventually hampered by shortages and socialist bureaucracy. Although based on standardized blocks in a park landscape the design had originally included several 
details aiming at small scale, legible structures and mixed use areas. ${ }^{80}$ But already in the mid-1970s Ursynów was no longer being built according to the original plan. ${ }^{81}$

The church became the most conspicuous signifier of this approach. It stands at the centre of the development and opens on to a pedestrianized square flanked by mixeduse buildings, thus reproducing the urban principles of a traditional small-town square: centrality, variation and incremental growth.

Budzyński considered these aspects to be the most important elements of his design. Already in 1981, shortly after construction had started, he pointed out that urban aspects were among the foremost qualities of his design. ${ }^{82}$ A year later he summarised his design as '.. an attempt to connect to the past, to the street, to the square.... ${ }^{83}$ Forty years later he still stressed that 'the principle of the small street' on which Ursynow is based, and that in this sense the surroundings of the church were 'a city within the city. ${ }^{, 84}$ Also the formal references to historical small-town ensembles were intentional from the very beginning - or, as Budzyński put it, "the basic leitmotiv is... the reference to things already existing..., not the search for anything "new.", 85

The church was not just symbolically the creator of an urban ensemble as in Poland churches were frequently parts of larger ensembles in which the sacred space was surrounded by several subsidiary buildings. The Ascension Church likewise came to be such a 'little town' (figure 11). There were various public or semi-public spaces, including a spacious crypt, sacristy, presbytery, church hall, parish archive, library and classrooms for Sunday school. There were in addition offices for different parish institutions, plus residences for seven priests and vicars. With slightly over 4,600 square metres floor space on 0.8 hectares the Ursynów Church ensemble was only about 20 per cent larger than those in comparably-sized parishes. ${ }^{86}$ [figure 11 near to here]

By mere dint of this programme and social function, the Ascension Church thus implicitly promoted the goals of post-functionalist urban planning. For a group of priests and church employees it provided living and working in close proximity. It drew pedestrian traffic and facilitated social gatherings in a society with not too many opportunities for socializing outside the workplace. Children would use the spaces outside the church for play after mass or religious education classes and neighbours would have a chat on their way to Bible study group or choir rehearsal. For all these activities and interactions the central square proved to be highly successful.

To some extent these urban qualities were enhanced by the Archdiocese Commission. In March 1981 Budzyński and Wicha deferred to the Commission's wishes and agreed to surround the church with a plain square without any ramps or stairs. Justified by the need to conduct processions, this was a major aspect that enhanced the concept of the pedestrian-oriented small-town square. ${ }^{87}$ The architects also decided to change the open-work church tower to the solid medievalist one that was eventually built, supposedly to increase its visibility from the big road and serve as a marker of the church ensemble. ${ }^{88}$ The request to pay particular attention to the square was repeated in other recommendations made by the Commission. ${ }^{89}$

The post-functionalist urban context was nonetheless just as much promoted by the architects. To date, the most conspicuous buildings next to the church are five-storey walk-up buildings flanking the square and forming the Pasaż Ursynowski (Ursynów 
Arcades, built 1995-97, design by Marek Budzyński, Anna Koziołkiewicz and Piotr Wicha). (figure 12) They contain flats and commercial spaces-including Budzyński's own home and office - as well as shops and a café. Although built shortly after the end of the socialist regime, their design was based on a regulatory plan, which Budzyński and his colleagues had begun before the church was completed. ${ }^{90}$ The plan was closely connected with the church ensemble. [figure 12 near to here]

Budzyński and his team expressed their vision in a 1982 document, pointing at some key aspects of post-functionalist planning. Their goal was to create 'a new portion of the city formed and functioning according to the model of the traditionally designed city centre. ${ }^{91}$ They also saw the city as characterised by different forces that at the one hand aim at regulation and control of the "interests of the "whole" and on the other hand at "uncontrolled development. 92 What the architects clad in rather abstract terms is a straightforward criticism of the centrally planned socialist model in favour of a regulated system of multiple actors (like for example such as the capitalist welfare state). There should be 'maximum freedom enabling the efficient realization of investment' and a 'scale and value of concrete investment many times smaller than that of the projected urban ensemble.' There should also be an 'organiser' such as a housing association that owns the land. ${ }^{93}$ These positions were repeated in the expertise on the project by a municipal planning office. This document praised Budzyński's, Koziołkiewicz's and Wicha's proposal for 'multiple-function and multiple-investor elements,' called for a 'coordinator' such as the housing association, which should also be financially responsible for the infrastructure, and proposed to legislate a binding master plan to which the different actors would be subjected. ${ }^{94}$ These principles were comparable to a highly regulated capitalist city composed of independent actors building on individual parcels, who have certain liberties with regard to their plot, but are nonetheless controlled and regulated by an overarching entity (such as the municipality or the district council). (figure 13, figure 14) [figure 13, figure 14 near to here]

Needless to say that such quasi-capitalist structures went far beyond what the socialist rulers were ready to establish as a new urban paradigm, and far beyond what they could afford given the slumping economy. They nonetheless were not unlike the structures that at the time were established in several Polish cities in response to a weakening central planning apparatus. Examples include the parcel-based redevelopment by small housing associations or cooperatives in Wrocław or in Elbląg. Here, diverse, quasiprivate and highly regulated institutions developed urban housing under the auspices of a municipal 'organiser.' 95

In this respect the plans for the Ursynów Arcades evidence the direction of urban design under late socialism. They show that Budzyński's postmodern principles-small scale, historic references, and traditional block structures-were connected to the postfunctionalist vision of a functionally mixed, pedestrian oriented city created by multiple actors within a tight regulatory framework. Very little of these visions would remain after the end of the socialist regime, when the once omnipotent central planning apparatus was not replaced by a regulatory framework of local 'organisers,' but rather by makeshift policies and laissez-faire. 


\section{Conclusion: Postmodernism, Power, and the City}

The Ascension Church in Warsaw-Ursynów shows postmodernism's potential to reconcile conflicting desires for historicity and innovation. The church and its surrounding buildings referred to a city of the future that was decidedly different to the functionalist ideas inherent in the tower blocks: a dense and functionally mixed urban environment that was connected community values and social cohesion. The eclectic historical references also catered to a deliberately unspecific image of a desirable national past, patriotic narratives, and a society centred on the Catholic Church. This was particularly effective in a context in which 'Polishness,' however defined, possessed unambiguously positive connotations and was claimed by very different political factions. In this context the building helped to catalyse long-standing nationalist ideas that gained momentum in the last decade of socialism and remained influential thereafter.

The church architecture reflects the changing power relations in late socialist Poland. The conditions of a weakening authoritarian regime were opportune for a certain form of postmodernism. They allowed for increasing international exchange and growing anti-functionalist criticism enabled by less restrictive censorship; and they provided opportunities for individualized design favoured by a fledgling market economy. With regard to the latter the unusual design bears witness to committed individuals such as Budzyński and Wojdat, who defied economic shortages and political repression to promote sophisticated architecture and innovative urban design. (figure 15) The building thus points to the leeway of individual action under an oppressive government, which set the stage to the profound changes in Poland after the end of socialism. [figure 15 near to here]

The Ascension Church shows that postmodernism in Poland was not an architecture of resistance or unambiguously associated with the political opposition. It was not the style of the people as opposed to official functionalist architecture, and can hardly be categorized along the lines of the Polish protesters' habitual distinction between 'us' and 'them'. While the socialist rulers tended to be noncommittal about stylistic questions the conditions for postmodernism were created through both government policy and dissident practice, and the significance of the building developed in relation to the political context.

Despite certain similarities the postmodern architecture of the Ascension Church attained a different meaning from comparable postmodern buildings in Western Europe or North America. International influences were adopted selectively and connected to local narratives. This applied in particular to historic quotations and the use of 'speaking' forms, which were employed differently than by Charles Moore, Robert Venturi or the other international architects whose works were popularized in Poland at the time. They were not used to criticize the architectural discipline or engage in an ironic play with no-longer-venerated traditions, but rather to bridge the contradictory aspirations for tradition and innovation. The history of the Ascension Church therefore shows that postmodern architecture did not carry a homogeneous and unchanging sociopolitical significance around the world, but rather derived its meaning from the local context in which it was developed and interpreted.

\section{Captions}


Figure 1: The Ascension Church in Warsaw-Ursynów (1980-85, design: Marek Budzyński and Piotr Wicha) (author).

Figure 2: Belltower, Ascension Church (author).

Figure 3: Stairs to the side entrance, Ascension Church - according to some a reference to the perron at the famous late-sixteenth-century palace in Baranów Sandomierski/South Poland (author).

Figure 4: Father Tadeusz Wojdat, parish priest of the Ascension Church, with construction workers, c. 1981 (courtesy T. Wojdat).

Figure 5: Ascension Church, model, c. 1980. The open-work belltower and the design of the subsidiary buildings on the left was later modified (courtesy T. Wojdat).

Figure 6: Ascension Church, interior with 'hanging columns' (author).

Figure 7: Ascension Church, construction site, c. 1981 (courtesy T. Wojdat).

Figure 8: Ascension Church, drawing, published in 1981 (Archiwum Akt Nowych, Warsaw).

Figure 9: Ascension Church, drawing of interior, still with traditional columns, published in 1981 (Archiwum Akt Nowych, Warsaw).

Figure 10: Ascension Church, construction site, c. 1982 (courtesy T. Wojdat).

Figure 11: Ascension Church, subsidiary buildings c. 1987 (courtesy T. Wojdat).

Figure 12: Ursynów Arcades, planned since 1981, built 1995-97, design by Marek Budzyński, Anna Koziołkiewicz and Piotr Wicha (author)

Figure 13: Spatial study for the Ursynów Arcades by Marek Budzynski, Piotr Wicha, Jerzy Rotowski/ Miastoprojekt Warszawa, Ursynów Polnocny, Projekt Centrum, Koncepcja, dated June 1981, plan 4 (Archiwum Biura Organizacji Urzędu Miasta, Warsaw)

Figure 14: Plan with church and Ursynów Arcades by Marek Budzynski, Piotr Wicha, Jerzy Rotowski/ Miastoprojekt Warszawa, Ursynów Polnocny, Projekt Centrum, Koncepcja, dated June 1981, plan 2A 'preferred version' (Archiwum Biura Organizacji Urzędu Miasta, Warsaw)

Figure 15: Ascension Church in 2018 (author) 
${ }^{1}$ This applies particularly to the early conceptions of postmodernism during the 1970 s and 1980 s, which were implicitly aimed at promoting, justifying or qualifying the new architectural movement. But it can also be found in more recent, purely historical accounts.

For the former, see for example Charles Jencks, The Language of Postmodern Architecture (New York: Rizzoli, 1977) and subsequent editions; Robert Stern, 'At the Edge of Postmodernism' [1977] reprinted in Architecture on the Edge of Postmodernism: Collected essays 1964-88 (New Haven: Yale University Press, 2009); Paolo Portoghesi, Postmodern: l'architettura nella societá post-industriale (1982); Heinrich Klotz, Die Revision der Moderne (Munich: Prestel, 1984).

For the latter, see for example Nan Ellin, Postmodern Urbanism (New York: Princeton Architectural Press, 1996); Mark Crinson and Claire Zimmerman, eds., Neo-avant-garde and Postmodern. Postwar Architecture in Britain and Beyond (New Haven: Yale University Press, 2010); Kathleen James-Chakraborty, 'From Postmodern to Neomodern: the United States and Europe' in Kathleen James-Chakraborty, Architecture Since 1400 (Minneapolis: University of Minnesota Press, 2014): Reinhold Martin, Utopia's Ghost: Architecture and Postmodernism, Again (Minneapolis: University of Minnesota Press, 2010) or Akos Moravanszki and Torsten Lange, eds., Re-framing Identities - Architecture's Turn to History 1970-1990 (Basel: Birkhäuser, 2017).

${ }^{2}$ See for example Lidia Klein and Alicja Gzowska, eds., Postmodernizm polski-architektura $i$ urbanistyka (Warsaw: Wydawnictwo 40000 Malarzy, 2013) or the special number 'Architektura Postmodernizmu' of the journal Autoportret 63 n. 4 (2018) with contributions by Aleksandra Stępień-Dąbrowska, Piotr Winskowski, Łukasz Wojciechowski and others. See also Łukasz Stanek, Postmodernizm jest prawie w porzadku: polska architektura po socjalistycznej globalizacji (Warsaw: Bęc Zmiana, 2012), 59-72 [in Polish and English] or Lidia Klein and Alicja Gzowska, 'Late Socialist Postmodernism and Socialist Realism in Polish Architecture' in Vladimir Kulić, ed., Second World Postmodernisms (London: Bloomsbury, 2018).

${ }^{3}$ Estimates vary between 1,000 and 2,000 in the whole country between 1970 and 1989. Konrad Kucza-Kuczyński, Nowe kościoły w Polsce (Warsaw: PAX, 1991), 11. On new sacred architecture in the context of political change see for example Konrad Kucza-Kuczyński, Widzialne niewidzialnego - nowe kościoły warszawskie (Warsaw: Oficyna Wydawnicza Politechniki Warszawskiej, 2015) or Izabela Cichońska, Karolina Popera, Kuba Snopek, Architektura siódmego dnia (Warsaw: Bęc Zmiana, 2016); for a critique of semiotics in recent church architecture see Anna Maria Wierzbicka, Architektura jako narracja znaczeniowa (Warsaw: Oficyna Wydawnicza Politechniki Warszawskiej, 2013). On the political conditions see Andrzej Basista, Betonowe Dziedzictwo - Architektura w Polsce czasów komunizmu (Warsaw: Wydawnictwo Naukowe PWN, 2001) or Błażej Ciarkowski, Odcienie szarości. Architekci i polityka w PRL-u (Łódź: Politechnika Łódzka, 2017).

${ }^{4}$ Marek Budzyński. 'Trochę wolności, trochę czasu...' [interwiew] Tygodnik Powszechny 36 n. 49 (5 December 1982), 7; Marek Budzyński and Piotr Wicha [interview] 'Kościół na Ursynowie Północnym w Warszawie’ Architektura 36 n. 1/407 (May-June 1982), 61-69; Marek Budzyński, 'Pasaż Ursynowski' [interview with Marek Budzyński, Anną Koziołkiewicz and Piotr Wicha] Architektura 417 n. 1 (1984), 32-2, 42-2; Marek Budzyński et al., 'Najbardziej ludzka sypialnia - Ursynów trzydzieści lat później' Architektura-Murator n. 6 (2005) 64-72; Marek Budzyński, 'Rozmowa' in Alicja Gzowska and Lidia Klein, Postmodernizm Polski Rozmowy z Architektami (Kraków: Stowarzyszenie 40000 Malarzy, 2013), 5-60.

${ }^{5}$ See for example Krzysztof Mycielski, 'Ursynów wczoraj i dziś' Archtektura Murator n, 12 (1998), 46-9; Lidia Pańkow, Bloki w stońcu - mała historia Ursynowa Pótnocnego (Sękowa: Czarne, 2016); Andrzej Rogiński, Historia Ursynowa - Okiem dziennikarza (Warszawa: Południe, 2017).

${ }^{6}$ The 'national communists' fashioned themselves as protectors of the fatherland against the onslaught of the Church, most infamously in the row over the Letter of Reconciliation of the 
Polish Bishops to the German Bishops in 1965. See for example Brian Porter-Szücs, Poland in the Modern World (Chichester: Wiley, 2014), 248-50. Likewise, the Church since the $19^{\text {th }}$ century, with national chauvinist and anti-Semitic connotations, promoted the equation PoleCatholic. See for example Brian Porter-Szücs, Faith and Fatherland-Catholicism, Modernity, and Poland (Oxford: Oxford University Press, 2011), 328-59.

${ }^{7}$ See for example the analysis of sociologist Jan Sowa, who claims that the long decline of the regime had begun with de-Stalinization in 1956. Jan Sowa, Inna Rzeczpospolita jest możliwa. Widma przeszłości, wizje przyszłości (Warsaw: Foksal, 2015), 123.

${ }^{8}$ On the economic crisis of the early 1980s and the rulers attempts to 'rescue socialism' see Dariusz Grala, Reformy gospodarcze w PRL (1982-1989). Próba uratowania socjalizmu (Warsaw: Trio, 2005), in particular 125-183.

${ }^{9}$ These reforms were a slow, step-by-step process. A market economy with freely operating businesses was eventually established in December 1988 with the passing of the 'Wilczek Law' that effectively ended the socialist planned economy.

${ }^{10}$ Buildings in general were not critically reviewed in Architektura, and there is evidence that the low quality of construction was occasionally not allowed to be published. But censorship was hardly applied to theoretical debates or discussions over stylistic expression. Andrzej Basista, Betonowe Dziedzictwo - Architektura w Polsce czasów komunizmu (Warsaw: Wydawnictwo Naukowe PWN, 2001), 52; Maciej Miłobędzki, architect, conversation with the author, Warsaw, 25 July 2018; Grzegorz Buczek, former secretary of SARP, conversation with the author, 12 November 2018.

${ }^{11}$ In particular 'Postmodernizm 1979' Architektura 33 n. 379-380 (May-June 1979), 70-74.

${ }^{12}$ See for example Tadeusz Barucki's one-page editorial 'Co dalej?' p. 24, the article 'Ostatnie dwadzieścia lat w architekturze' pp. 24-45, which is a shortened version of Paul Hans Peters's 'Aspekte einer neuen Freiheit in der Architektur' (published in Baumeister in 1978), and 'Żegnajcie szklane pudełka' pp. 46-53, a shortened version of Robert Hughes's 'Doing their own thing' (published in Time Magazine in 1979), all in Architektura 33 n. 379-380 (May-June 1979).

${ }^{13}$ Marek Budzyński and Andrzej Kicinski, interviewed by Czesław Bielecki, Architektura $33 \mathrm{n}$. 379-380 (May-June 1979), 52.

${ }^{14}$ Jerzy Buszkiewicz, interviewed by Andrzej Bruszewski Architektura 32 n. 379-380 (MayJune 1979), 69.

${ }^{15}$ See also 'Poszukiwanie stylu narodowego w architekturze polskiej ostatniego stulecia' Architektura n. 2/403 (March-April 1977).

${ }^{16}$ There is no evidence of a particular directive allowing for increasing church construction. According to architectural historian Konrad Kucza-Kuczyński, rather, it was a practice backed by Gierek. Konrad Kucza-Kuczyński, Widzialne niewidzialnego - nowe kościoły warszawskie (Warsaw: Oficyna Wydawnicza Politechniki Warszawskiej, 2015), 28, and Konrad KuczaKuczyński, conversation with the author, Warsaw, 27 November 2018.

${ }^{17}$ Urząd Miasta Stołecznego Warszawy, Wydział do Spraw Wyznań, Memo 'Budownictwo sakralne i kościelne1945-87’, 1987?, Archiwum Państwowe w Warszawie 72/2305, p. 42. ${ }^{18}$ Even the Politburo acknowledged 'the activities of the Church leadership in calming down the stirred minds [of the striking workers in 1980] and encouraging their return to work.' Minutes of Politburo meeting on 23 September 1980, report 'Sytuacja spoleczno-polityczna oraz kierunki dzialania partii i Panstwa' Archiwum Akt Nowych, Inventory 'Polska Zjednoczona Partia Robotnicza, Komitet Centralny w Warszawie, Biuro Polityczne’ V/157, vol. 4 (July-September), p. 438. For the position of the Church in the protests see also Brian PorterSzücs, Poland in the Modern World (Chichester: Wiley, 2014), 292-6.

${ }^{19}$ For an analysis of the economic crisis and the different proposals to resolve it through economic reforms see Dariusz Grala, Reformy gospodarcze w PRL (1982-1989). Próba uratowania socjalizmu (Warsaw: Trio, 2005), 91. 
${ }^{20}$ This is evident in the rulers' feverish attempts to end the protests without giving in. See for example Minutes of Politburo meeting on 23 September 1980, report 'Sytuacja społecznopolityczna oraz kierunki działania partii i państwa' Archiwum Akt Nowych, Inventory 'PZPR, KC, Biuro Polityczne' V/157, vol. 4 (July-Sept), p. 438.

${ }^{21}$ Most significant were the reinvented old town Nikolaiviertel and the entertainment district Friedrichstraße in East Berlin. Florian Urban, Neo-historical East Berlin (Farnham: Ashgate, 2009), 99-142 and 181-214.

${ }^{22}$ Kazimierz Kłos, 'Kościół na Ursynowie’, WTK Tygodnik Katolicki (Warsaw) n. 3, 18 January 1981, 1-3.

23 'Kościół na Ursynowie Północnym w Warszawie' Architektura 36 n. 1/407 (May-June 1982), $61-9$

${ }^{24}$ Henryk Drzewiecki, 'Ruch nowoczesny w architekturze sakralnej: nowosc a tradycja mysli klasycznej' Architektura 37 n. 5/415 (September 1983), 23.

${ }^{25}$ Paweł Giergoń, quoted in Lidia Pańkow, Bloki w słońcu - mała historia Ursynowa Pólnocnego (Sękowa: Czarne, 2016), 208.

${ }^{26}$ Tadeusz Wojdat, conversation with the author, Warsaw, 16 August 2018.

${ }^{27}$ Marek Budzyński and Piotr Wicha [interview] 'Kościół na Ursynowie Północnym w Warszawie' Architektura 36 n. 1/407 (May-June 1982), 65

${ }^{28}$ Florian Urban, Neo-historical East Berlin (Farnham: Ashgate, 2009), 237-9.

${ }^{29}$ Even in the 1970s Party documents are full of patriotic rhetoric, conjuring 'the development of the Polish nation.' See for example Minutes of the Politburo Meeting on meeting on 2 October 1979. Projekt Wytycznych na VIII Zjazd PZPR „O dalszy rozkwit socjalistycznej Polski, o rozwój narodu polskiego' Archiwum Akt Nowych, Inventory ‘PZPR, KC, Biuro Polityczne' V/153, vol. 4 (Oct-Dec).

${ }^{30}$ This applies particularly to the Archdiocese Commission. Konrad Kucza-Kuczyński, conversation with the author, Warsaw, 27 November 2018.

${ }^{31}$ Konrad Kucza-Kuczyński, conversation with the author, Warsaw, 27 November 2018. Kucza-Kuczyński accompanied Budzyński on this trip.

${ }^{32}$ Ibid.

${ }^{33}$ Krzysztof Kieślowski, Dekalog I, 1988, originally produced for Polish Television.

${ }^{34}$ Marek Budzyński, quoted in Magdalena Kaczorowska and Andrzej Kaczorowski, Pierwszy na Ursynowie - Ks. Prałat Tadeusz Wojdat i Kościót Wniebowstapienia Pańskiego (Warsaw: Self-published, 2015), 46; Henryk Drzewiecki, 'Ruch nowoczesny w architekturze sakralnej: nowość a tradycja myśli klasycznej’ Architektura 37 n. 5/415 (September 1983), 23.

${ }^{35}$ Ibid., 46; Tadeusz Wojdat, conversation with the author, Warsaw, 16 August 2018; Marek Budzyński, conversation with the author, Warsaw, 6 August 2018.

${ }^{36}$ Such symbolic occupations were for example the 'field masses,' unauthorised open-air gatherings at which a priest celebrated a mass. This was a frequent practice in 1980s Poland, and often related to popular protest. See for example memorandum dated 24 April 1987, Urząd Miasta Stołecznego Warszawy Wydział do Spraw Wyznań, Budownictwo sakralne i kościelne 1985-89, Archiwum Państwowe w Warszawie 72/2305, call number 30, p. 103

${ }^{37}$ Tadeusz Wojdat, quoted in Kazimierz Kłos, 'Kościół na Ursynowie’, WTK Tygodnik Katolicki (Warsaw) n. 3, 18 January 1981, 1-3.

38 Józef Jaroń, vice-director of the Wydział do Spraw Wyznań, Warsaw City Administration, , Memorandum 'Tezy do rozmów z biskupem Jerzym Modzelewskim' dated 8 September 1978 (after the talk) Archiwum Akt Nowych, Urząd do Spraw Wyznań 108/15, p. 27.

${ }^{39}$ Tadeusz Wojdat, letter to Jerzy Majewski, Mayor of Warsaw, dated 18 October 1978, Archiwum Akt Nowych Urząd do Spraw Wyznań 108/18, p. 201.

${ }^{40}$ Wydział do Spraw Wyznań, Warsaw City Administration Archiwum Państwowe Warsaw $72 / 2305$, p. 9

${ }^{41}$ Tadeusz Wojdat, conversation with the author, 6 September 2018. 
${ }^{42}$ Andrzej Rogiński, Historia Ursynowa - Okiem dziennikarza (Warszawa: Południe, 2017), 37; Tadeusz Wojdat, conversation with the author, 6 September 2018.

${ }^{43}$ Opinion by the session of the Kuria Metropolitalna, dated 23 September 1981, Archiwum Archidiecezjalne Warsaw, PR 248.

${ }^{44}$ Kazimierz Kłos, 'Kościół na Ursynowie', WTK Tygodnik Katolicki (Warsaw) n. 3, 18 January 1981, 1-3.

${ }^{45}$ Magdalena Kaczorowska and Andrzej Kaczorowski, Pierwszy na Ursynowie - Ks. Prałat Tadeusz Wojdat i Kościół Wniebowstąpienia Pańskiego (Warsaw: Self-published, 2015), 43.

${ }^{46}$ Ibid., 43-46; Marek Budzyński, conversation with the author, Warsaw, 6 August 2018.

${ }^{47}$ Tadeusz Wojdat, conversation with the author, Warsaw, 16 August 2018.

${ }^{48}$ The significance of Glemp's opinion was confirmed by both Budzyński and Wojdat. Marek Budzyński, conversation with the author, Warsaw, 6 August 2018; Tadeusz Wojdat, conversation with the author, Warsaw, 6 September 2018.

${ }^{49}$ Tadeusz Wojdat, conversation with the author, Warsaw, 16 August 2018, Marek Budzyński, conversation with the author, Warsaw, 6 August 2018.

${ }^{50}$ Tadeusz Wojdat, conversation with the author, 6 September 2018.

${ }^{51}$ See for example Minutes of the meeting of the Komisja Artystyczna i Architektoniczna Archidiecezji Warszawskiej, dated 26 March 1981 and 11 September 1981, Archiwum Archidiecezjalne Warsaw, PR 248. Architectural historian Konrad Kucza-Kuczyńsk remembered the level of debate as rather low. Konrad Kucza-Kuczyński, conversation with the author, Warsaw, 27 November 2018.

52 The Primate's Council had grown out of the consultative commission for the rebuilding of churches destroyed in the Second World War; its remit ranged from publishing calendars and bulletins to giving loans to churches for renovations. It had about 30 members, including Bolesław Szmidt, the co-founder of the Liverpool School of Architecture during the Second World War, Mieczysław Twardowski, the author of the standard work on church construction published by the Council, church architect Władysław Pieńkowski, and Warsaw Politechnika professor Konrad Kucza-Kuczyński. Rada Prymasowska Budowy Kościołów Warszawy, members list 1980-85, Archiwum Archidiecezjalne Warsaw, PR 59.

${ }^{53}$ See for example Minutes of the meeting of the Komisja Artystyczna i Architektoniczna Archidiecezji Warszawskiej, dated 26 March 1981 and 11 September 1981, Archiwum Archidiecezjalne Warsaw, PR 248. Members included the architects Bolesław Szmidt, Władysław Pieńkowski, Lech Dunin, Tadeusz Zieliński and the priest Edward Żmijewski.

${ }^{54}$ Minutes of the meeting of the Komisja Artystyczna i Architektoniczna Archidiecezji Warszawskiej, dated 11 September 1981, Archiwum Archidiecezjalne Warsaw, PR 248. ${ }^{55}$ Ibid. ${ }^{56}$ Ibid.

${ }^{57}$ Minutes of the meeting of the Komisja Artystyczna i Architektoniczna Archidiecezji Warszawskiej, dated 26 March 1981, Archiwum Archidiecezjalne Warsaw, PR 248. ${ }^{58}$ Ibid.

${ }^{59}$ Kazimierz Kłos, 'Kościół na Ursynowie', WTK Tygodnik Katolicki (Warsaw) n. 3, 18 January 1981, 1-3.

${ }^{60}$ This motto does not appear in any architectural or planning document, but has been widely used since the early 1980s. Ibid.

${ }^{61}$ Minutes of the meeting of the Komisja Artystyczna i Architektoniczna Archidiecezji Warszawskiej, 11 September 1981, Archiwum Archidiecezjalne Warsaw, PR 248.

${ }^{62}$ Marek Budzyński and Piotr Wicha [interview] 'Kościół na Ursynowie Północnym w Warszawie' Architektura 36 n. 1/407 (May-June 1982), 65

${ }^{63}$ Izabela Cichońska, Karolina Popera, Kuba Snopek, Architektura siódmego dnia (Warsaw: Bęc Zmiana, 2016), 32. 
${ }^{64}$ Wydział do Spraw Wyznań of the Warsaw City Administration, document 'Budownictwo sakralne i kościelne 1945-87,' Archiwum Państwowe, Warsaw 72/2305, p. 44.

${ }^{65}$ The Church Fund was a state institution incorporated in 1950 as a compensation for expropriated church property, paying for example for priests' pension schemes and church maintenance. Antoni Dudek and Ryszard Gryz, Komuniści i Kościót w Polsce (1945-1989) (Krakow: Znak, 2006), particularly 13-14.

${ }^{66}$ Jerzy Gurawski, 'Rozmowa' in Klein, Lidia and Alicja Gzowska Postmodernizm polskiarchitektura i urbanistyka. Rozmowy z architektami (Warsaw: Wydawnictwo 40000 Malarzy, 2013), 298

${ }^{67}$ Tadeusz Wojdat, conversation with the author, Warsaw, 16 August 2018.

${ }^{68}$ Andrzej Rogiński, Historia Ursynowa - Okiem dziennikarza (Warszawa: Południe, 2017), 39.

${ }^{69}$ Tadeusz Wojdat, conversation with the author, Warsaw, 16 August 2018.

${ }^{70}$ Tadeusz Wojdat, quoted in Kazimierz Kłos, 'Kościół na Ursynowie’, WTK Tygodnik Katolicki (Warsaw) n. 3, 18 January 1981, 1-3.

${ }^{71}$ Tadeusz Wojdat, conversation with the author, Warsaw, 16 August 2018.

${ }^{72}$ Slightly over 600 złoty for one dollar in 1985, Brian Porter-Szücs, Poland in the Modern World (Chichester: Wiley, 2014), 309.

${ }^{73}$ Wydział do Spraw Wyznań of the Warsaw City Administration, Memorandum dated 21 January 1985, Archiwum Państwowe, Warsaw 72/2305, p. 109.

${ }^{74}$ Tadeusz Wojdat, conversation with the author, Warsaw, 16 August 2018.

${ }^{75}$ By this I mean the principles that became popular among urban planners since the 1990s, such as small scale, functional mixture, visible historicity, and support of non-automotive traffic, summarized for example in Nan Ellin, Postmodern Urbanism (New York: Princeton Architectural Press, 1996).

${ }^{76}$ For a passionate criticism of functionalist tower block developments and top-down planning, which surprisingly made it through the censorship organs see Czesław Bielecki, 'Zdepczemy osiedla i trawniki,' Polityka 18 n. 32 (1974), 3. The author, 26 years old at the time, later became a regular contributor to Architektura, and in the 1980s was jailed for participation in the Solidarity protests before founding one of Poland's first private architectural practices.

${ }^{77}$ Journalist Lidia Pańkow calls Alexander 'Budzyński’s private guru' Lidia Pańkow, Bloki w stońcu - mała historia Ursynowa Pólnocnego (Sękowa: Czarne, 2016), 52-4 and 66. He also figures prominently in Bielecki's criticism Czesław Bielecki, 'Zdepczemy osiedla i trawniki,' Polityka 18 n. 32 (1974), 3.

${ }^{78}$ Ibid.

${ }^{79}$ Florian Urban, The New Tenement (Abingdon: Routledge, 2018), 51-4.

${ }^{80}$ Budzyński, Marek, 'Ursynów Północny - uwarunkowania, zasady' Architektura n. 1-2 (January-February 1975)

${ }^{81}$ Marek Budzyński, conversation with the author, Warsaw, 6 August 2018.

${ }^{82}$ Marek Budzyński, quoted in minutes of the meeting of the Komisja Artystyczna i

Architektoniczna Archidijecezji Warszawskiej, dated 26 March 1981, Archiwum

Archidiecezjalne Warsaw, PR 248.

${ }^{83}$ Marek Budzyński and Piotr Wicha [interview] 'Kościół na Ursynowie Północnym w Warszawie' Architektura 36 n. 1/407 (May-June 1982), 66.

${ }^{84}$ Marek Budzyński, conversation with the author, Warsaw, 6 August 2018.

${ }^{85}$ Marek Budzyński, quoted in Kazimierz Kłos, 'Kościół na Ursynowie', WTK Tygodnik Katolicki (Warsaw) n. 3, 18 January 1981, 1-3.

86 'Kościół na Ursynowie Północnym w Warszawie' Architektura 36 n. 1/407 (May-June 1982), 61; Tadeusz Wojdat, conversation with the author, Warsaw, 16 August 2018. 
${ }^{87}$ Minutes of the meeting of the Komisja Artystyczna i Architektoniczna Archidiecezji Warszawskiej, dated 26 March 1981, Archiwum Archidiecezjalne Warsaw, PR 248.

${ }^{88}$ Ibid.

${ }^{89}$ Opinia Sesji Kurii Metropolitalnej, dated 23 September 1981, Archiwum Archidiecezjalne Warsaw, PR 248.

${ }^{90}$ Marek Budzynski, Zbigniew Badowski, Anna Koziołkiewicz, Piotr Wicha, 'Plan Koordincyjny Pasaż Ursynowski’ dated December 1982, Archiwum Biura Organizacji Urzędu Miasta, Warsaw (no call number).

${ }^{91}$ Ibid., 1.

${ }^{92}$ Marek Budzyński, Zbigniew Badowski, Anna Koziołkiewicz, Piotr Wicha, 'Założenia warunkujące osiągnięcia celu' in booklet 'Plan Koordinacyjny Pasaż Ursynowski' dated December 1982, Archiwum Biura Organizacji Urzędu Miasta, Warsaw (no call number), p. 2-3. ${ }^{93}$ Ibid.

${ }^{94}$ Zofia Hamanowa, Director of Pracownia Urbanistyczna 'Południe,' handwritten expertise on Pasaż Ursynowski, addressed to Urząd Miasta Stołecznego Warszawy, Wydział Urbanistyki, Architektury i Ochrony Środowiska, dated 17 June 1983, in folder 'Korespondencja dotycząca Budowy Pasażu Ursynowskiego’ 1983-85 Archiwum Biura Organizacji Urzędu Miasta, Warsaw, call number 2276/673,

${ }^{95}$ See for example Łukasz Medeksza, 'Wrocławskie plomby jako strategia polityczna," Pamięć i przyszłość n. 37-38 (2017), 23-41; Maria Lubocka-Hoffmann, Elblag Stare Miasto (Elbląg: Państwowa Służba Ochrony Zabytków w Elblągu, 1998), 25-30. 


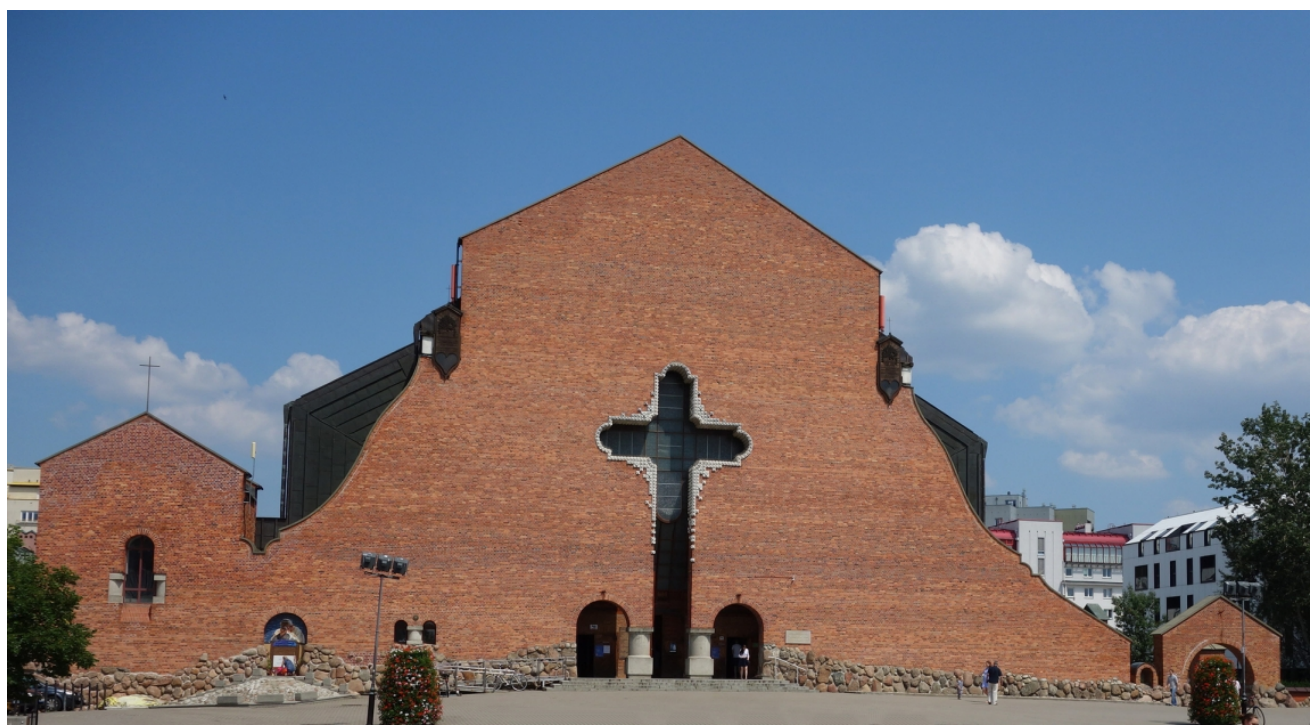

Figure 1: The Ascension Church in Warsaw-Ursynów (1980-85, design: Marek Budzyński and Piotr Wicha) (author).

$161 \times 88 \mathrm{~mm}(300 \times 300$ DPI $)$ 


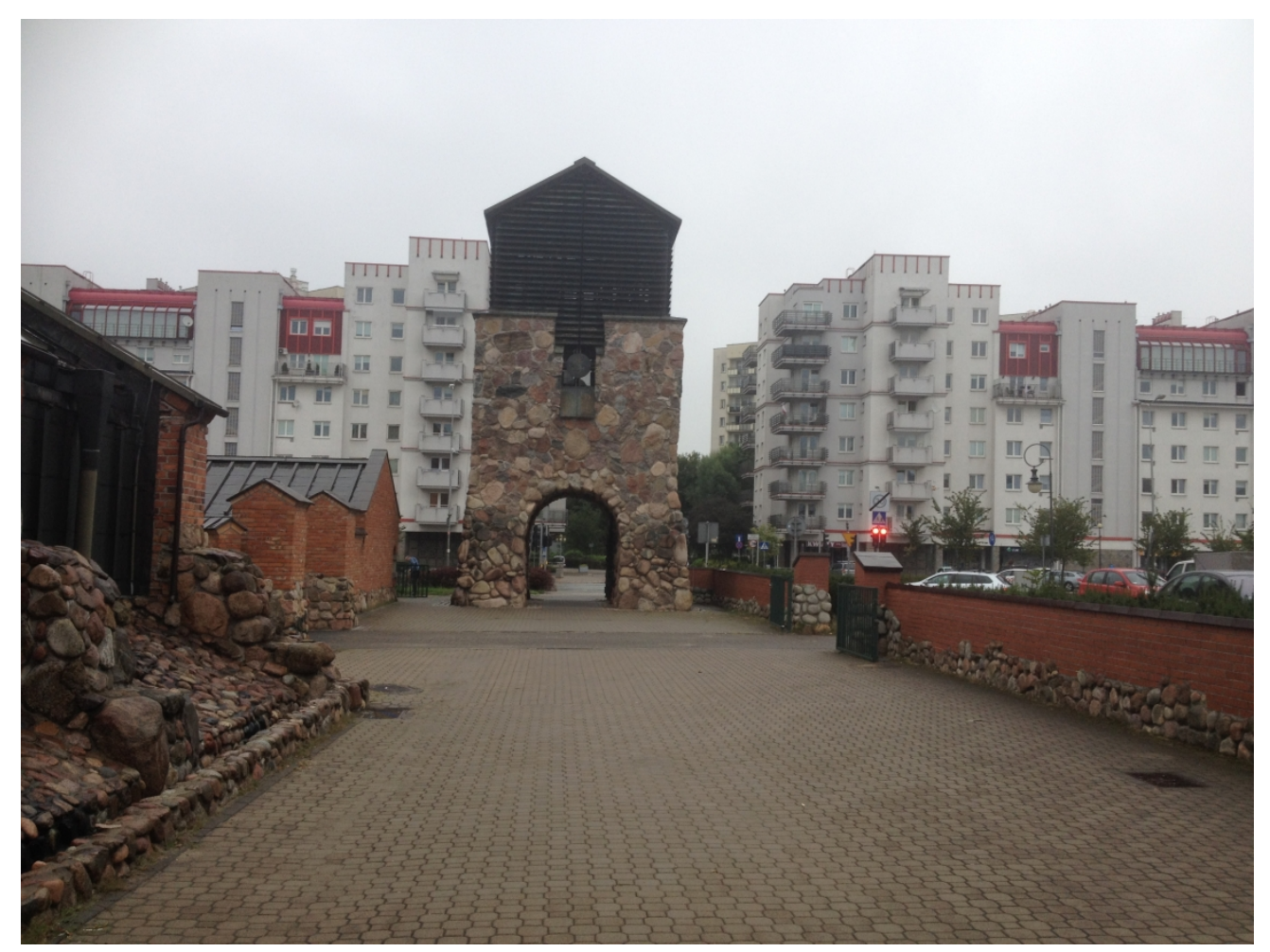

Figure 2: Belltower, Ascension Church (author). $1151 \times 863 \mathrm{~mm}(72 \times 72 \mathrm{DPI})$ 


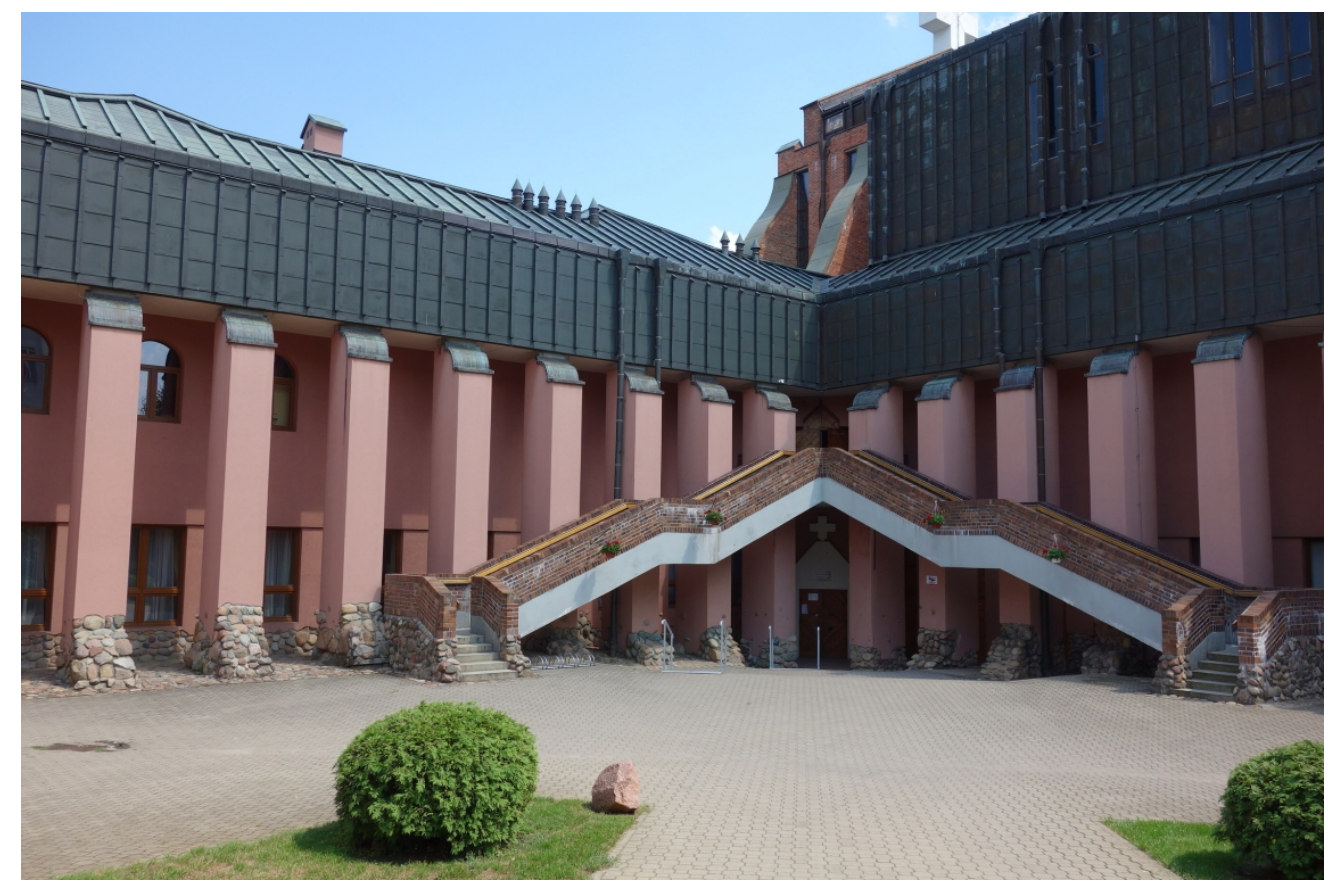

Figure 3: Stairs to the side entrance, Ascension Church - according to some a reference to the perron at the famous late-sixteenth-century palace in Baranów Sandomierski/South Poland (author).

$$
198 \times 132 \mathrm{~mm}(300 \times 300 \mathrm{DPI})
$$




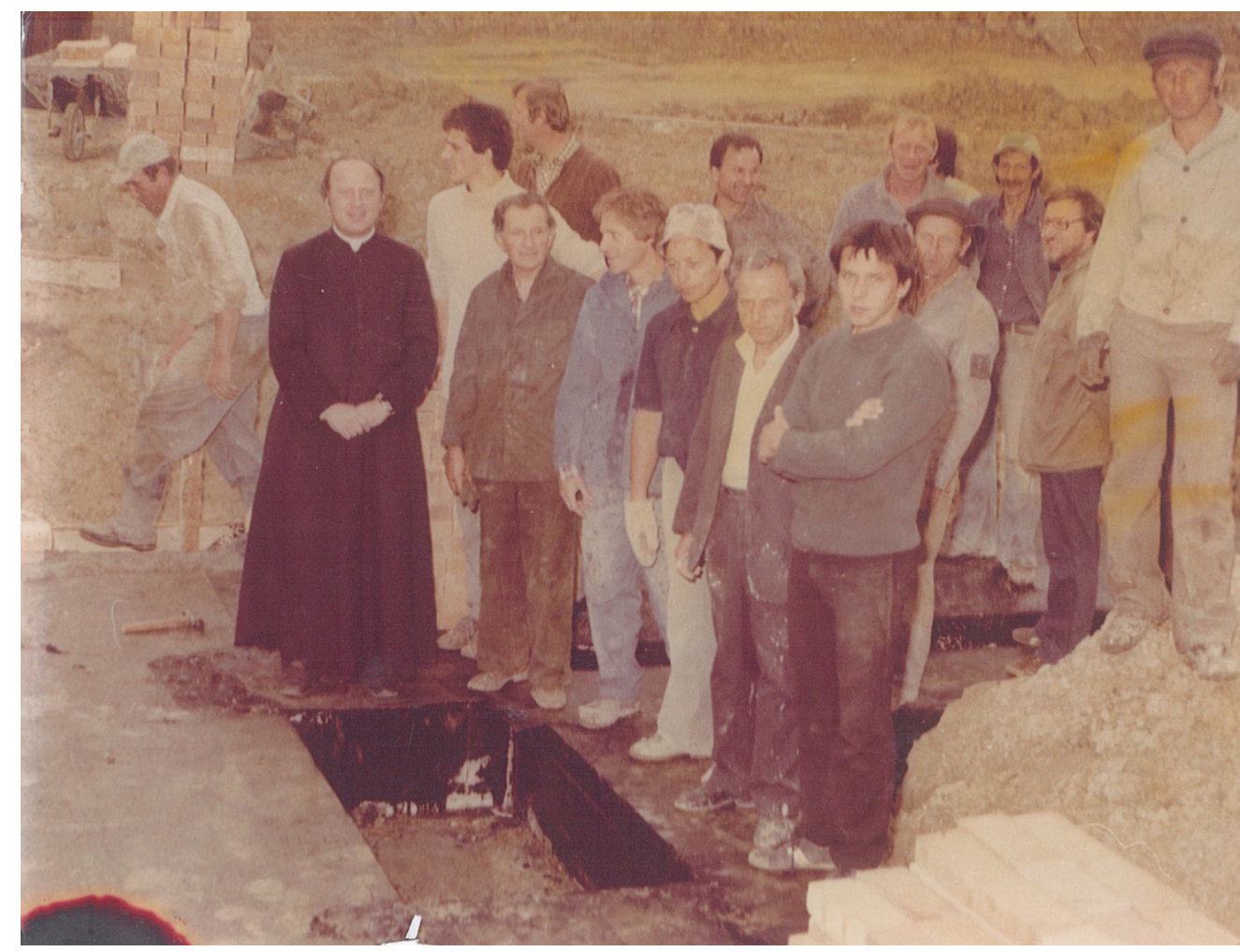

Figure 4: Tadeusz Wojdat, parish priest of the Ascension Church, with construction workers, c. 1981 (courtesy T. Wojdat).

$142 \times 109 \mathrm{~mm}(300 \times 300 \mathrm{DPI})$ 


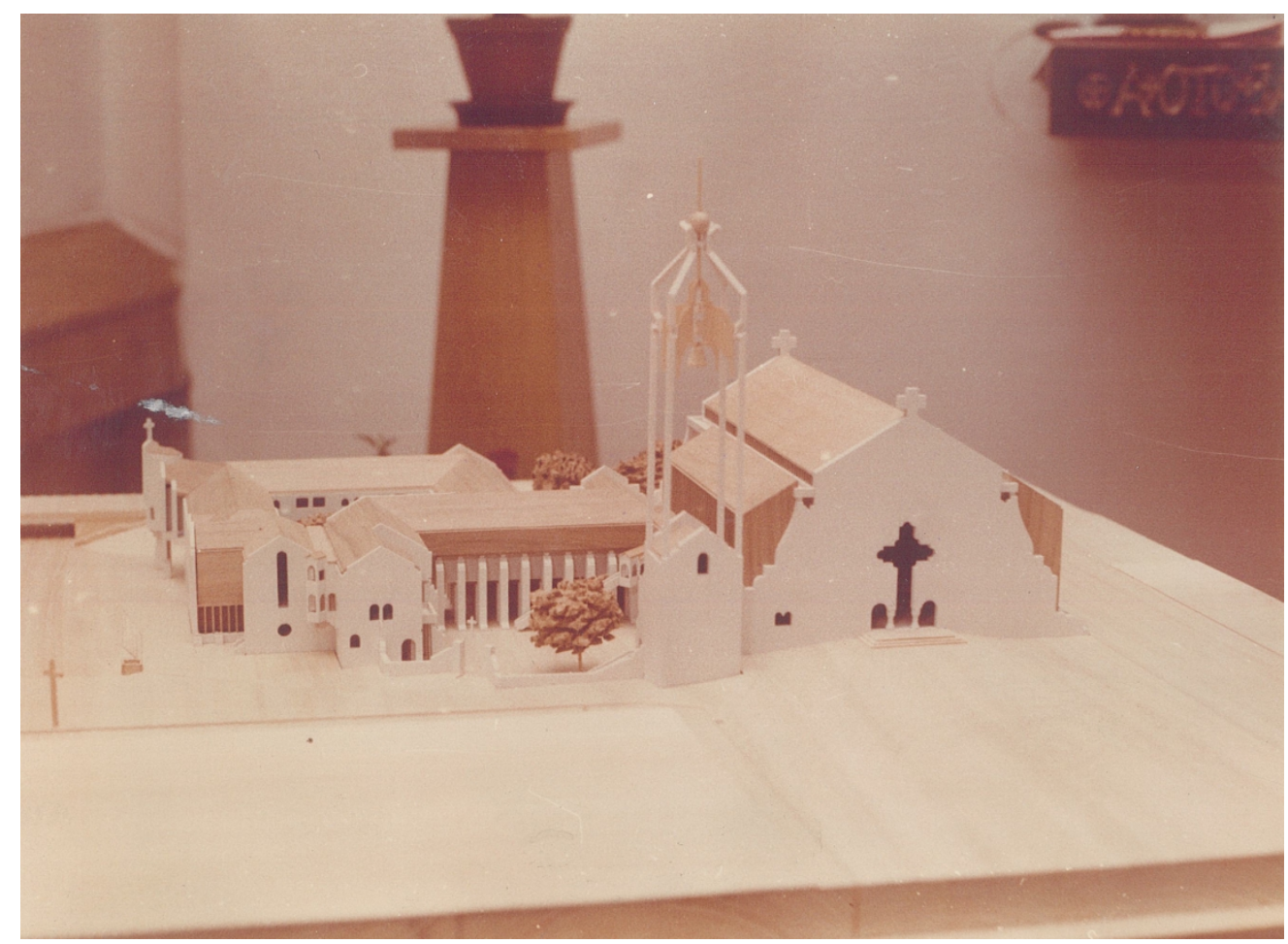

Figure 5: Ascension Church, model, c. 1980. The belltower and the design of the subsidiary buildings on the left was later modified (courtesy T. Wojdat).

$169 \times 124 \mathrm{~mm}(300 \times 300 \mathrm{DPI})$ 


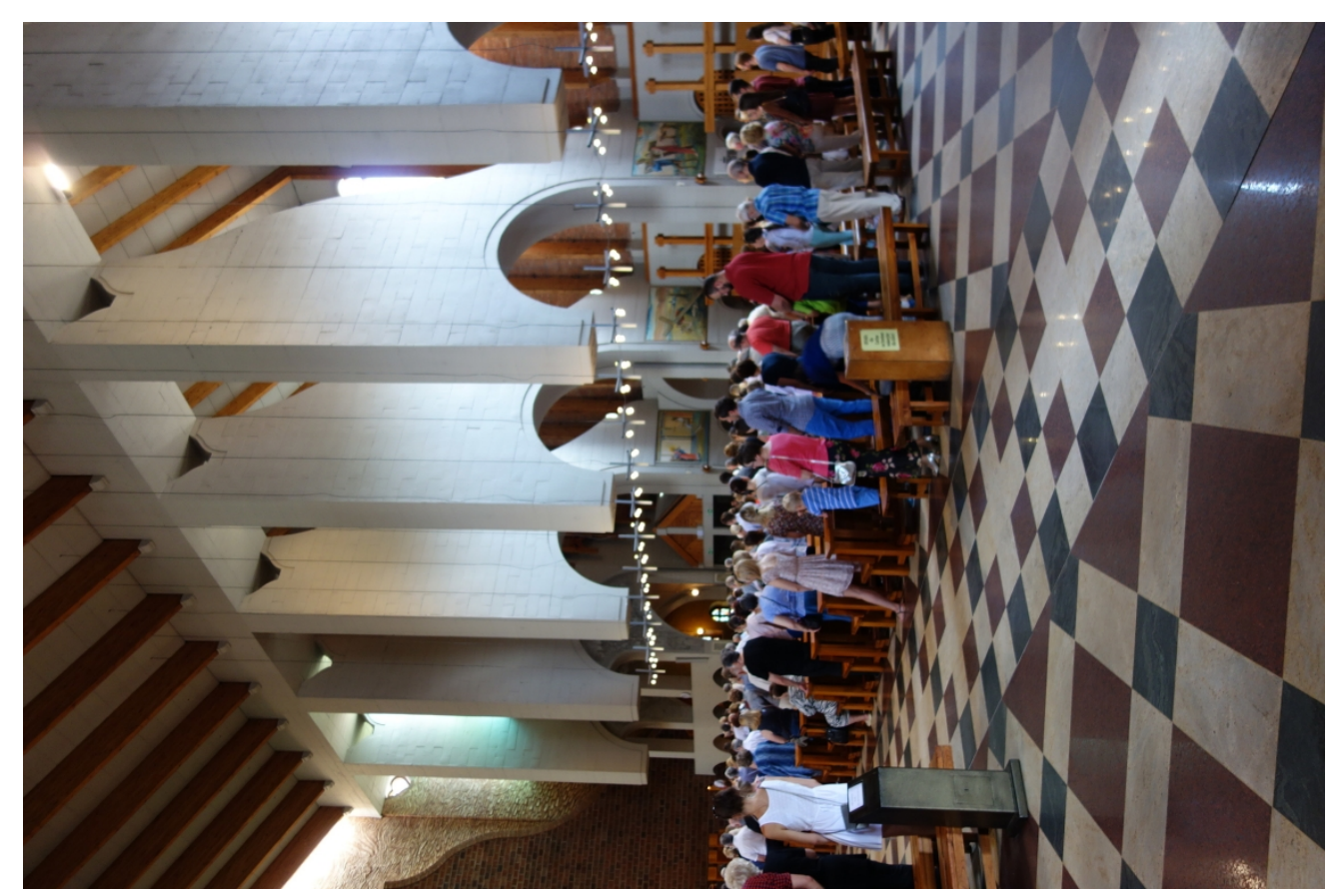

Figure 6: Ascension Church, interior with "hanging columns" (author).

$198 \times 132 \mathrm{~mm}(300 \times 300 \mathrm{DPI})$ 


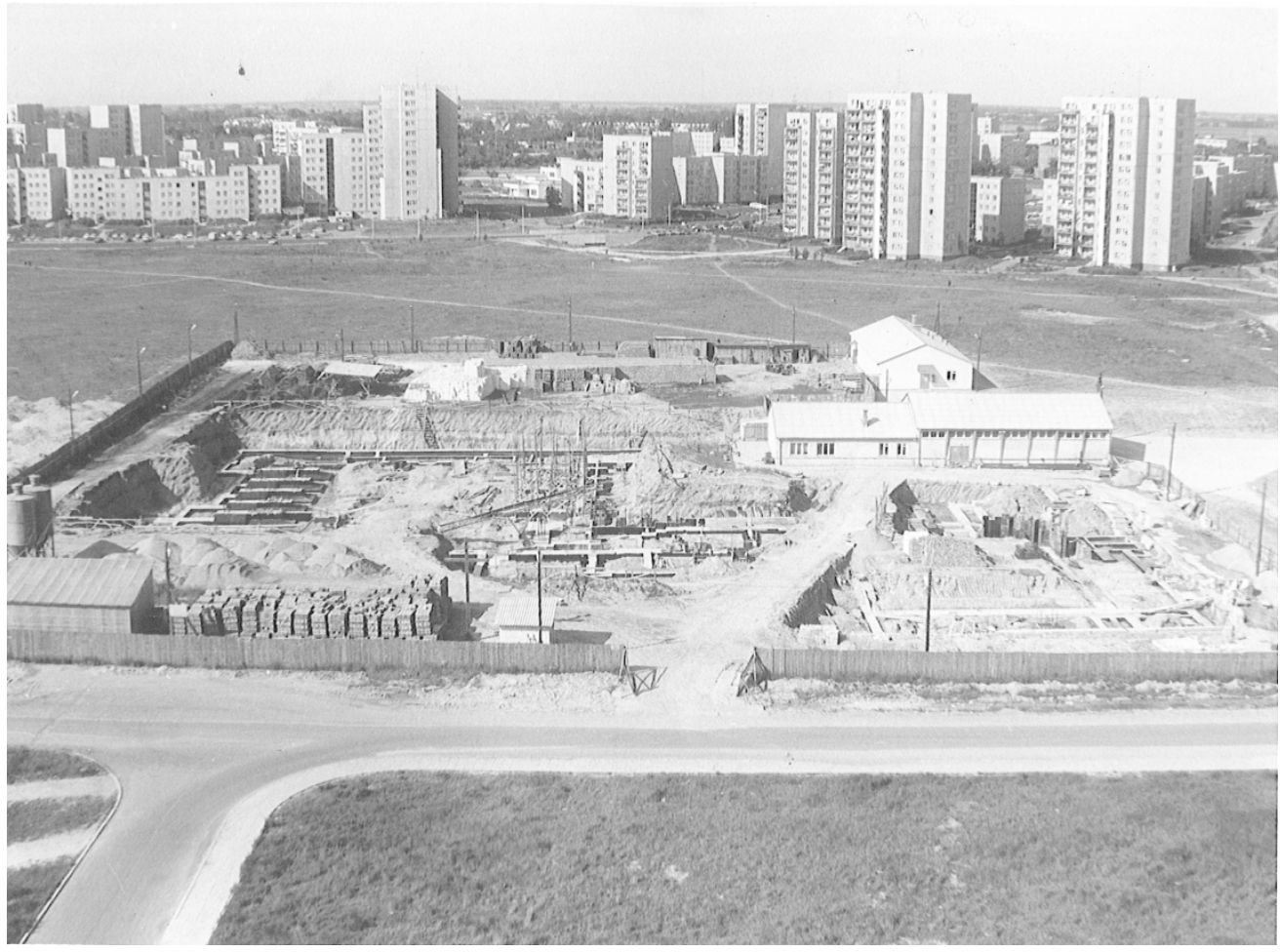

Figure 7: Ascension Church, construction site, c. 1981 (courtesy T. Wojdat). $169 \times 125 \mathrm{~mm}(300 \times 300 \mathrm{DPI})$ 


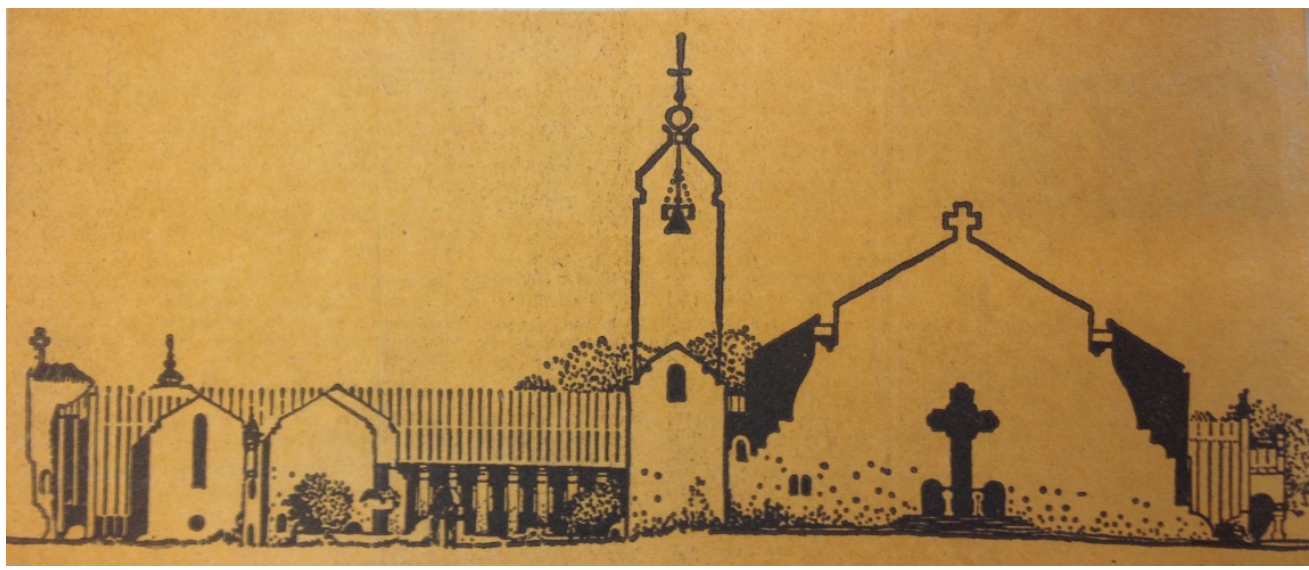

Figure 8: Ascension Church, drawing, published in 1981 (Archiwum Akt Nowych, Warsaw). $1018 \times 436 \mathrm{~mm}(72 \times 72 \mathrm{DPI})$ 


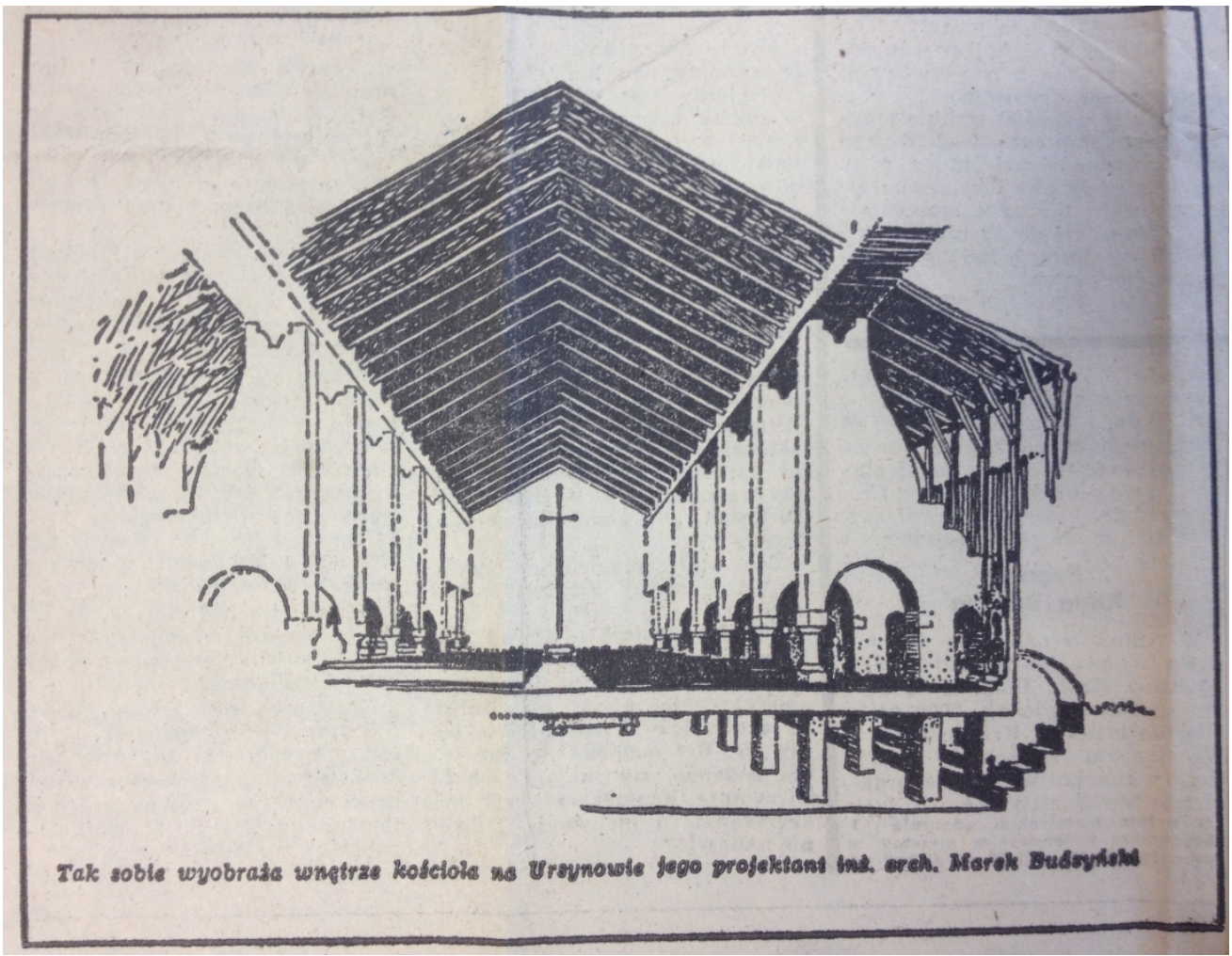

Figure 9: Ascension Church, drawing of interior, still with traditional columns, published in 1981 (Archiwum Akt Nowych, Warsaw).

$1002 \times 775 \mathrm{~mm}(72 \times 72 \mathrm{DPI})$ 


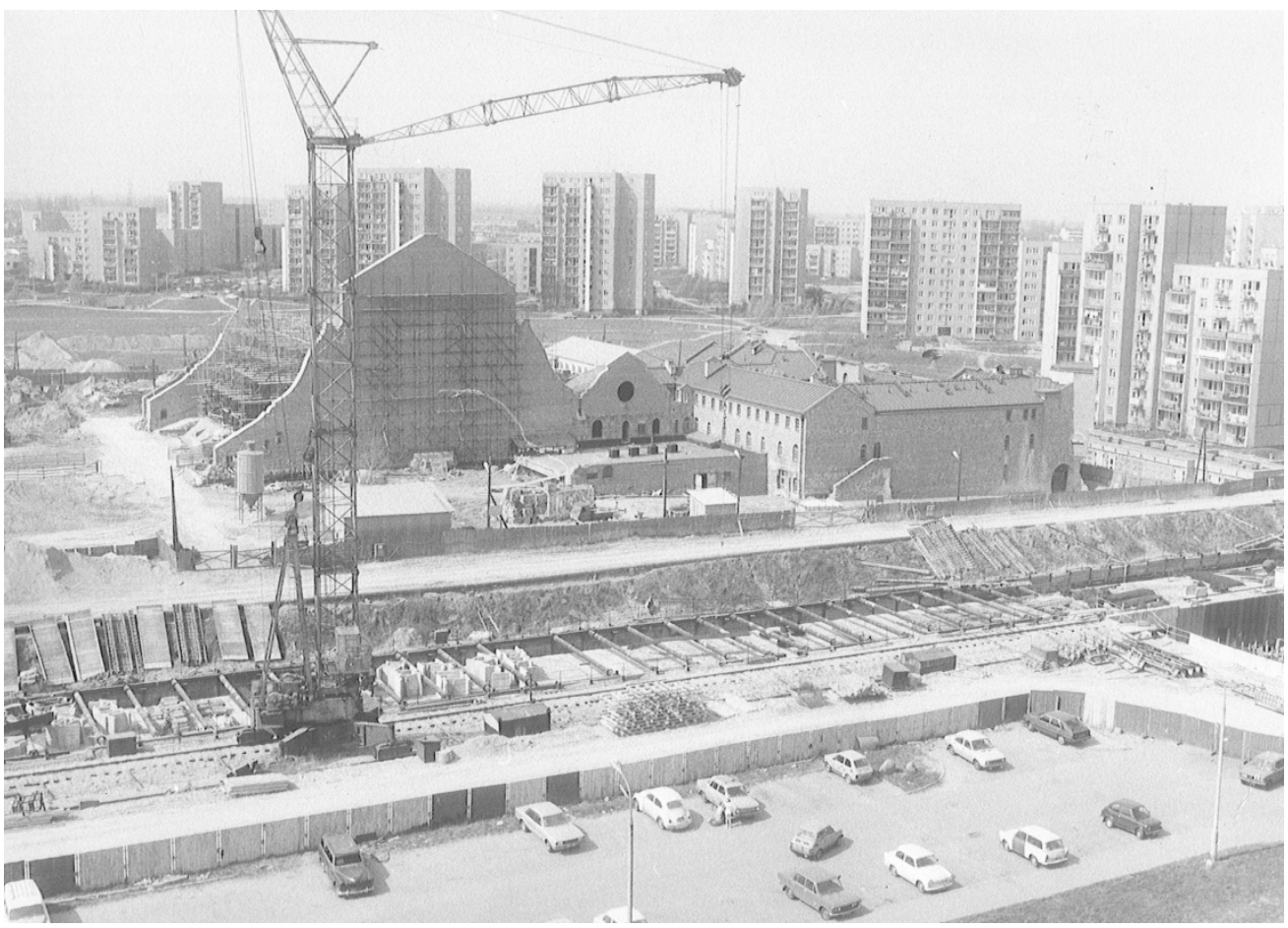

Figure 10: Ascension Church, construction site, c. 1982 (courtesy T. Wojdat). $168 \times 120 \mathrm{~mm}(300 \times 300 \mathrm{DPI})$ 


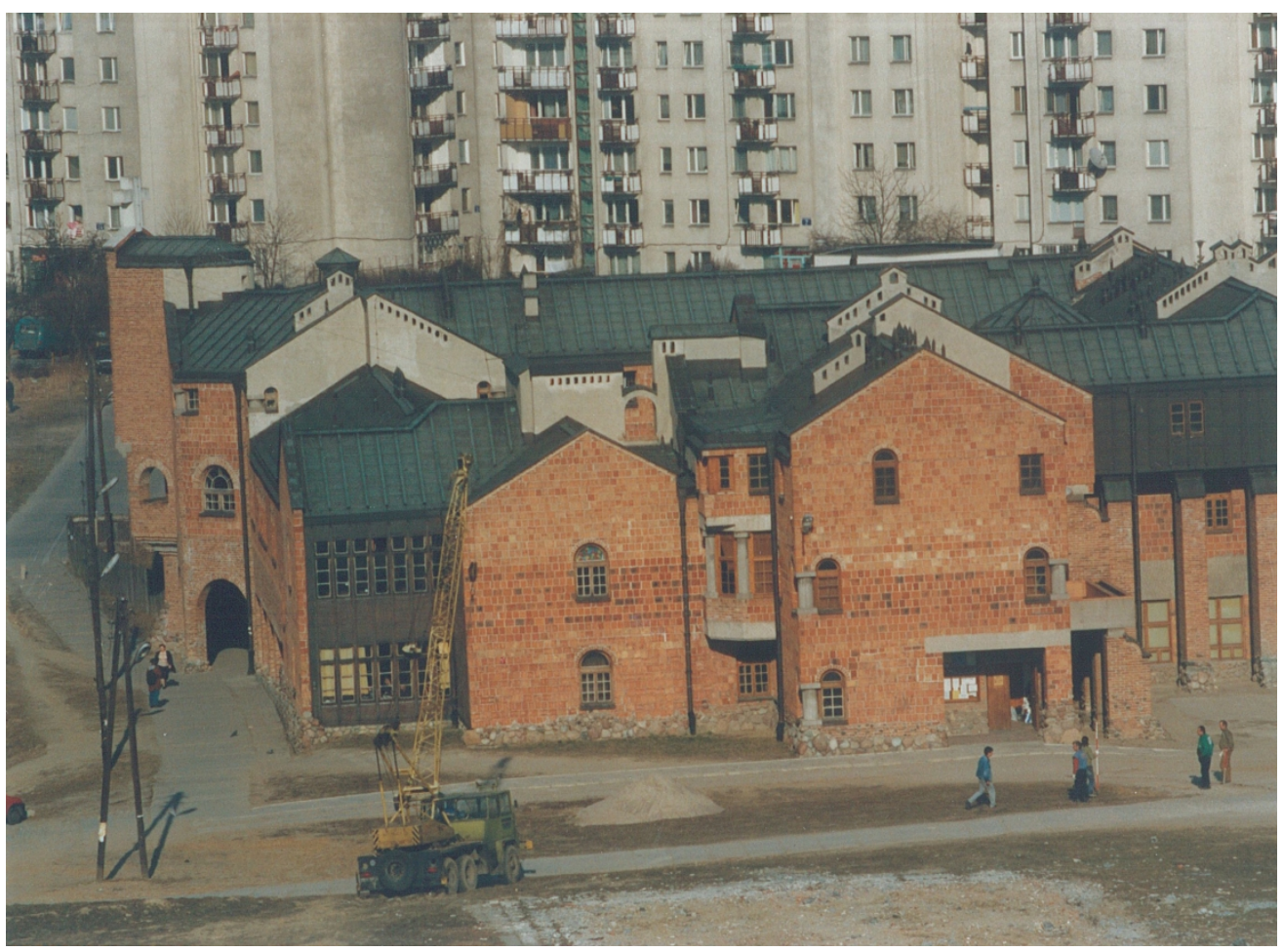

Figure 11: Ascension Church, subsidiary buildings c. 1987 (courtesy T. Wojdat). $171 \times 125 \mathrm{~mm}(300 \times 300 \mathrm{DPI})$ 


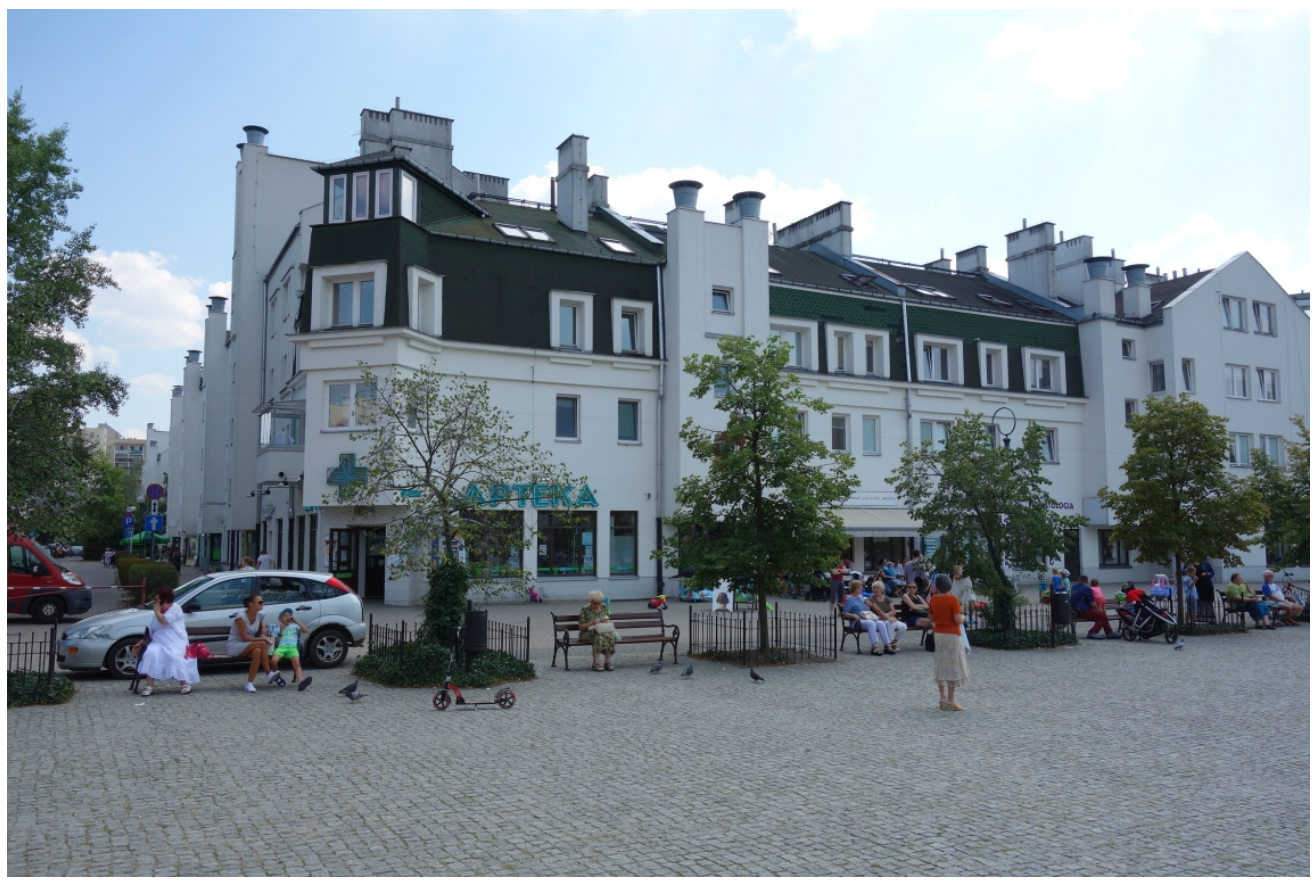

Figure 12: Ursynów Arcades, planned since 1981, built 1995-97, design by Marek Budzyński, Anna Koziołkiewicz and Piotr Wicha (author)

$$
198 \times 132 \mathrm{~mm}(300 \times 300 \mathrm{DPI})
$$


Figure 13: Spatial study for the Ursynów Arcades by Marek Budzynski, Piotr Wicha, Jerzy Rotowski/ Miastoprojekt Warszawa, Ursynów Polnocny, Projekt Centrum, Koncepcja, dated June 1981, plan 4 (Archiwum Biura Organizacji Urzędu Miasta, Warsaw)

$132 \times 198 \mathrm{~mm}(300 \times 300 \mathrm{DPI})$ 


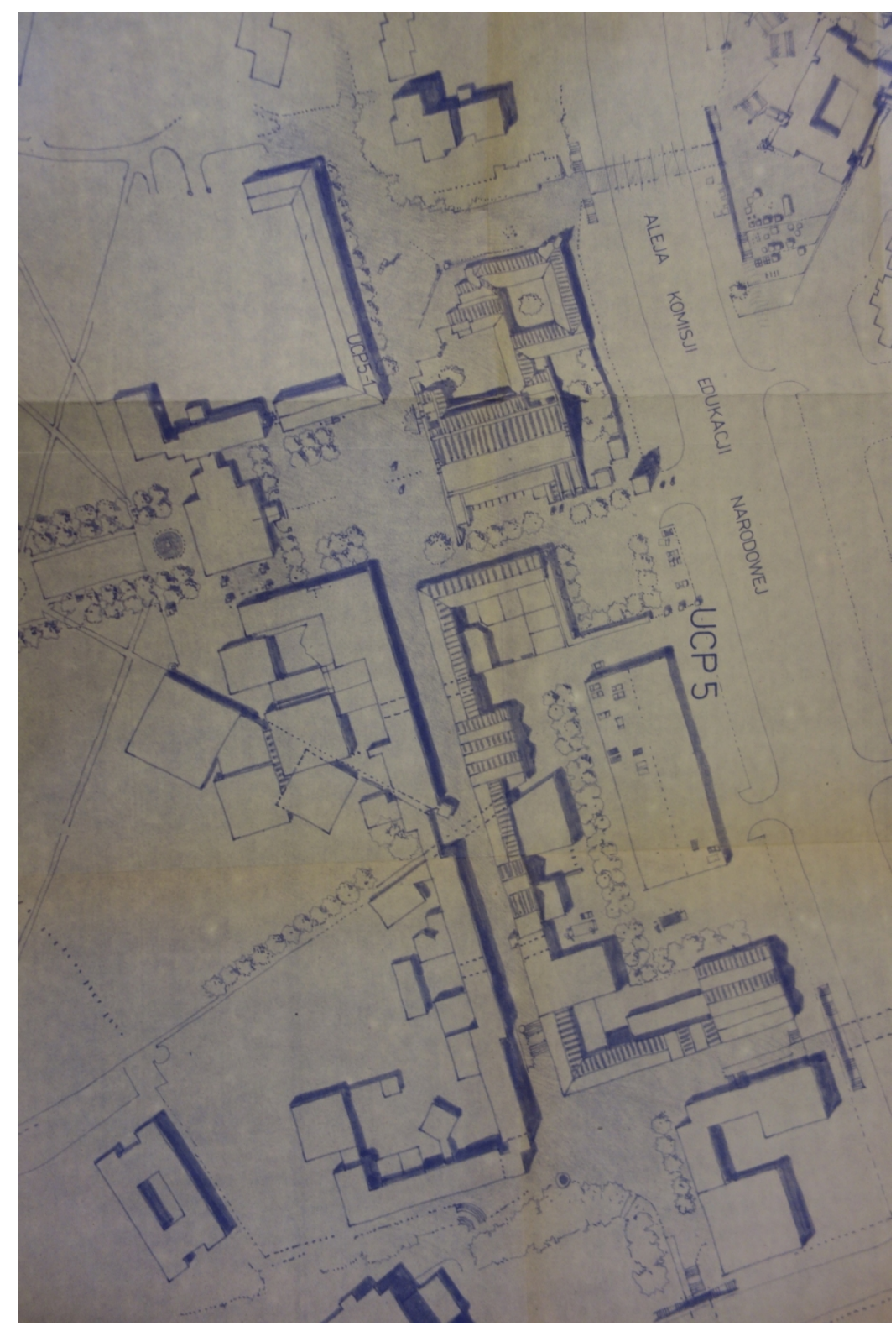

Figure 14: Plan with church and Ursynów Arcades by Marek Budzynski, Piotr Wicha, Jerzy Rotowski/ Miastoprojekt Warszawa, Ursynów Polnocny, Projekt Centrum, Koncepcja, dated June 1981, plan 2A „preferred version" (Archiwum Biura Organizacji Urzędu Miasta, Warsaw)

$132 \times 198 \mathrm{~mm}(300 \times 300 \mathrm{DPI})$ 


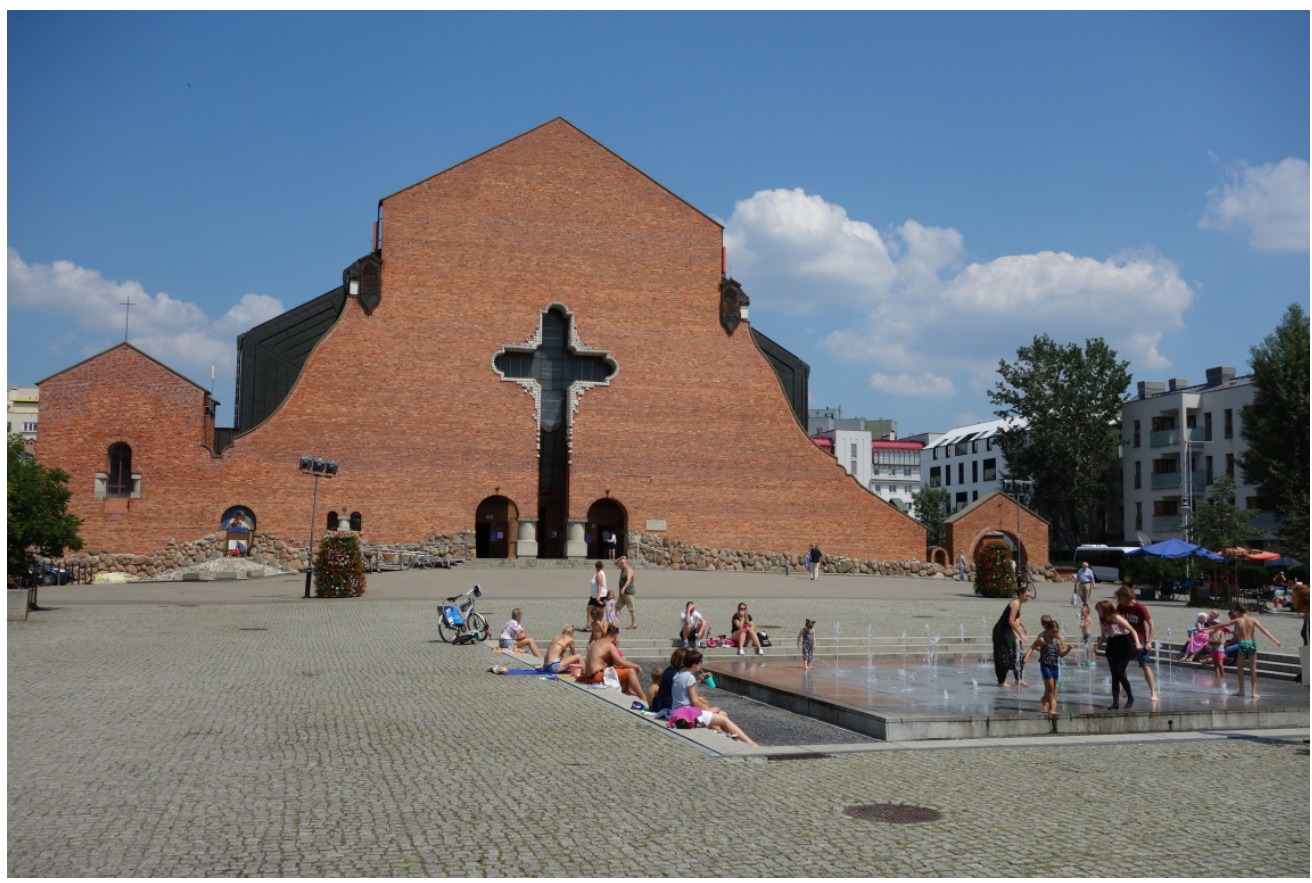

Figure 15: Ascension Church in 2018 (author) $198 \times 132 \mathrm{~mm}(300 \times 300 \mathrm{DPI})$ 